NBER WORKING PAPERS SERIES

\title{
HIGH-TECH CAPITAL FORMATION AND LABOR COMPOSITION IN U.S. MANUFACTURING INDUSTRIES: AN EXPLORATORY ANALYSIS
}

Emst R. Berndt

Catherine J. Morrison

Larry S. Rosenblum

Working Paper No. 4010

\author{
NATIONAL BUREAU OF ECONOMIC RESEARCH \\ 1050 Massachusetts Avenue \\ Cambridge, MA 02138 \\ March 1992
}

Research support from the U.S. Bureau of Labor Statistics, Office of Productivity and Technology, Division of Productivity Research, is gratefully acknowledged. Mr. Berndt also acknowledges research suppor from the Alfred P. Sloan Foundation. Portions of this paper originally appeared in Emst R. Bemdt and Catherine J. Morrison, "High-Tech Capital, Economic Performance and Labor Composition in U.S. Manufacturing Industries: An Exploratory Analysis," presented in honor of Zvi Griliches' 60th birthday, Jerusalem, May 1991. The authors have benefited from the comments of Zvi Griliches and Moshe Kim. This paper is part of NBER's research program in Productivity. Any opinions expressed are those of the authors and not those of the National Bureau of Economic Research. 


\title{
HIGH-TECH CAPITAL FORMATION AND LABOR COMPOSITION IN U.S. MANUFACTURING INDUSTRIES: AN EXPLORATORY ANALYSIS
}

\begin{abstract}
In this paper we report results of an exploratory empirical effort examining relationships between investments in high-tech information technology capital and the distribution of employment, both by occupation and by level of educational attainment. Our data cover the two-digit U.S. manufacturing industries, annually, 1968-86.

We find that increases in the high-tech composition of capital (OF/K) are positively related to growth in white collar, non-production worker hours, and that increases in white collar hours account for most of the reduction in aggregate labor productivity associated with increases in high-tech capital.

In terms of educational attainment, within the blue collar occupations we find clear evidence in support of skill upgrading toward more educated workers occurring along with increases in $O F / K$. While point estimates are not very precise, among white collar occupations we find that hours provided by the least and most educated workers increase with $O F / K$, while hours provided by those with high-school and some college education are adversely affected.
\end{abstract}

Ernst R. Berndt

Massachusetts Institute of Technology

50 Memorial Drive, E52.452

Cambridge, MA 02139

and NBER

Larry S. Rosenblum

U.S. Department of Labor

Office of Productivity and Technology

200 Constitution Avenue

Francis Perkins Building, S-4315

Washington, DC 20212
Catherine J. Morrison

Tufts University

Department of Economics

Breaker Hall 320

Medford, MA 02155 
HIGH-TECH CAPITAL FORMATION AND LABOR COMPOSITION

IN U.S. MANUFACTURING INDUSTRIES: AN EXPLORATORY ANALYSIS

by Ernst R. Berndt, Catherine J. Morrison and Larry S. Rosenblum

\section{INTRODUCTION}

The enormous potential of "high-tech" office and information (microelectronic chip) technology for achieving labor time and cost savings has been documented by many analysts. Whether in practice such potential benefits to increased labor productivity have in fact occurred is not nearly as wellrecorded. Indeed, while the evidence to date is far from conclusive, recent research results suggest that high-tech capital has not yet "delivered" as promised, at least in terms of its effects on traditionally measured productivity growth in a variety of US industries. 1

A relatively neglected issue in this controversy has been the effect of high-tech capital formation on the distribution of employment among occupations and skill classes of workers. Although the existing literature has provided controversial conjectures and anecdotal evidence, surprisingly little is known concerning such distributional impacts of high-tech capital formation. 2 These distributional impacts comprise the focus of this paper. Specifically, in this paper we report results of an exploratory data analysis based on annual two-digit manufacturing investment data by type of equipment from the US Bureau of Economic Analysis, merged with employment data by occupation and level of educational attainment constructed at the US Bureau of Labor Statistics. Using this annual 1968-86 data for twenty two-digit US manufacturing industries, we employ multiple regression procedures and relate the distribution of employment by occupation and level of educational attainment to, among other factors, the share of high-tech capital in total industry capital stock. 


\section{Overview of Existing Literature}

The empirical economics literature on the employment distribution effects of capital investment goes back at least to the work of Zvi Griliches, who in 1969 proposed the capital-skill complementarity hypothesis, summarized as follows:

"This is the idea that educated labor is complementary to, rather than a substitute for, various advanced forms of machinery and that therefore a rapid rate of capital accumulation (and innovation) will increase the demand for such labor and prevent the fall in its relative price." 3 In his empirical work, Griliches found that in U.S. manufacturing industries, physical capital and high-skill (more highly educated) workers were less substitutable (more complementary) than were low-skill (less educated) workers and physical capital. Similar evidence for manufacturing industries has been reported by Ernst R. Berndt and Laurits R. Christensen [1974] and by Catherine Morrison and Ernst R. Berndt [1981], who found that while production (blue collar) workers and physical capital are substitutable inputs, non-production (white collar) workers and physical capital are complementary. ${ }^{4}$

A related strand of economic research involves trends in the estimated rate of return to schooling. Here labor economists have noted that private gross rates of return to schooling fell somewhat in the 1970 s, but since then they have rebounded and increased considerably. Kevin Murphy and Finis Welch [1988] have speculated that this increase in gross rates of return to schooling in the 1980 s may be due to changes in the demand for skilled labor, reflecting in part the efforts of U.S. firms to remain competitive in the face of increased international competition. 5 This finding is also consistent with the hypothesis put forward by Ann P. Bartel and Frank R. Lichtenberg [1987], who argue that innovations in technology alter demand in favor of better educated workers because better educated workers have a comparative advantage in implementing new technology. 6 
Finally, in this context it is worth noting the intriguing finding reported recently by Alan B. Krueger [1991], in which he finds that wage rates of employees whose work involves computers receive an approximate $15 \%$ wage premium over other workers, holding education, age, experience and computer use at home fixed. 7 Although this finding is fascinating, in this paper we Iimit our attention to relations between high-tech capital investment and the quantity of employment by occupation and skill class, and leave for further research the analysis incorporating price (wage) effects.

It is also important to note that a closely related debate has emerged within the sociology literature. This highly controversial dispute is typically known as the deskilling hypothesis, and draws much of its inspiration from the writings of Harry Braverman [1974].

Braverman's contention is that within contemporary capitalism, a pervasive tendency prevails for jobs to be reorganized at lower skill levels than was previously the case; in this context, he argues that investments in high-tech office and information technology equipment degrade or deskill the work force. 8 According to Paul Attewell and James Rule [1984, p. 1185], Braverman's deskilling hypothesis has the following empirical implications:

"Deskilling manifests istself in two ways: intraoccupational changes, where the skill content of a particular job decreases over time, and interoccupational changes, where the number of people in skilled jobs shrinks and the number in less skilled jobs increases. In the second of these cases, one empirical indicator of deskilling is a shift in the occupational distribution of the white-collar work force. Thus, the deskilling position implies that new information technologies produce a more polarized pyramidical distribution of skill: a mass of unskilled clerical workers at the bottom, and a small number of 'conceptual workers' at the top, alongside management."

In contrast to the deskilling hypothesis, a number of analysts have argued that computerization and other new information technologies upgrade rather than deskill white and blue collar jobs. 9 According to these authors, computerization diffuses primarily into already-routinized work situations; 
high-tech capital takes the drudgery aspects out of information processing by automating the processes of filing and retrieving information, preparing repetitious paper work, moving messages, performing simple computational techniques, and monitoring the activities of agents. Since high-tech automation absorbs many of the manual tasks of information processing, workers have more time to concentrate on conceptual and decision-making tasks. Attewell-Rule [1984, p. 1185] summarize this as:

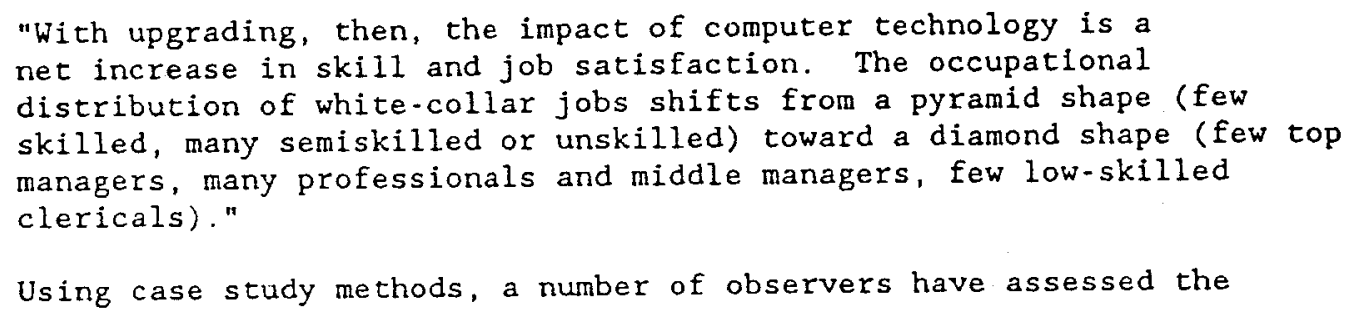

While the above literature overview in economics and sociology is admittedly brief, it does suggest a number of hypotheses about relationships among high-tech investment, economic performance, and labor composition that might be addressed in an exploratory data analysis. For example, with respect to the capital-skill complementarity hypothesis, one might examine whether increased physical capital intensity is more positively correlated with increases in non-production labor than with production labor. Holding overall physical capital intensity fixed, one could also assess whether high-tech information technology capital has a differential impact on production vs. non-production labor demand. In terms of the deskilling and upgrading 
conjectures, one might relate changes in high-tech capital with variations in the distribution of white collax worker employment by level of educational attainment; a similar examination could be undertaken on the effects of hightech capital formation on the distribution of blue collar employment by education.

In the remainder of this paper, we proceed to explore these types of issues. First, in the next section we will overview a number of measurement issues and data construction procedures emerging from the construction and application of our data; we will also provide a brief discussion of trends in these data. Then in Section IV we will report results based on multiple regression analysis, relating employment levels as well as the distribution of employment by occupation and level of educational attainment to various "explanatory" variables, including in particular aggregate capital intensity and the share of high-tech capital in total physical capital. Finally, in Section $V$, based on results of this data analysis, we will comment on a number of research issues that invite a more detailed structural analysis, to be pursued in subsequent research.

\section{Measurement and Data Issues}

\section{A. DATA CONSTRUCTION AND INTERPRETATION}

Given that we are interested in exploring the impacts of high-tech capital formation, it is useful to begin by considering what we mean by the notion of information and office rechnology equipment. Clear guidelines are not available to help define the concept of information technology capital, in part because there is as yet no well-articulated theory on precisely what tasks information technology performs. 11 For practical purposes, our possibilities are constrained considerably by the limited availability of public domain data. At the industry level of aggregation, such data appear to 
be restricted to the capital stock and investment series constructed by John A. Gorman et al. [1985] and John Musgrave [1986] of the Bureau of Economic Analys is (BEA), U.S. Department of Commerce.

Based on this BEA investment and capital stock data, we have constructed a "high tech" capital aggregate of office and information technology capital (hereafter, denoted as $O F$ ) as a Divisia index of four asset codes in the BEA data set: 14 - office, computing and accounting machinery (including computing and related machines, typewriters, scales and balances, and office machines not elsewhere classified); 16 - communications equipment; 25 scientific and engineering instruments; and 26 . photocopy and related equipment. We have also constructed an equipment aggregate EQ consisting of al1 24 components of non-OF producers' durable equipment, and a structures aggregate ST incorporating all 22 non-residential structure assets from the manufacturing industries.

Similarly, determining a useful breakdown for labor composition involves a number of measurement issues. The concept of skill, or, preferably, skills, is difficult to implement empirically. 12 presumably skills are related to the capacity to do various types of work. Not only are there mathematical and linguistic skills, but other important work-related skills involve perseverance, manual dexterity, physical capabilities, social skills, and organizational abilities. Although some work has been undertaken and published on the distribution of various skill requirements by occupation and industry for selected years, 13 annual time series data on skills by two-digit manufacturing data are not yet available.

For empirical implementation, therefore, we follow the precedent set by most of the previous literature and classify workers according to cognitive skills, assuming these are proxied by a measure of educational attainment. 14 Hence, we operationalize the skill concept by classifying workers according to 
their highest level of formal educational attainment - no high school

diploma, high school diploma, some college, or college degree. 15

A related set of issues emerges in defining occupation. In the 1970's, the U.S. Department of Labor, Bureau of Labor Statistics (BLS), initiated its Occupational Employment Statistics (OES) program in which employers are surveyed concerning job titles of their employees; in 1982, for example, employment in nearly 1,700 occupations was tabulated by three-digit industry. Unfortunately, the notion of occupation has changed along with technology, and thus there is a very difficult problem in defining occupations on a consistent basis over time. ${ }^{16}$ This time consistency problem is even more severe for the BLS Dictionary of Occupational Titles (DOT), a data base that lists over 12,000 specific occupations but includes no information at all on employment levels by occupations. Finally, the set of occupations listed in the decennial Census and in the monthly Current Population Survey is based on a US Department of Commerce Standard Occupational Classification (SOC) system which is inconsistent with both the OES and the DOT category classifications.

As a practical matter, problems in the time consistency of occupational titles are likely to be mitigated somewhat as one aggregates over detailed occupational groups. In the data base constructed for this study, therefore, employment by occupation is aggregated into two occupational groups -. nonproduction workers and production workers. Non-production workers include professional, technical and kindred workers; managers, officials, and proprietors, except farm; clerical and kindred workers except vehicle dispatchers and starters, shipping and receiving clerks, stock clerks and storekeepers; sales workers; service workers, except janitors, sextons, guards, watchmen and doorkeepers. Production workers include all other workers, such as craftsmen, foremen and kindred workers; operatives and kindred workers; and laborers. 
Several issues merit comment in interpreting this labor data. First, the underlying employment and earnings data by level of educational attainment are taken Erom the March Current Population Survey for the years 1968-89. Thus the data are subject to possible "occupational aggrandizement", for the respondent is the head of household, not the employer. 17

Second, the CPS measure of hours is essentially a count of the hours at work; hours of employees, unpaid family workers and proprietors are included in the CPS data provided the majority of their hours were worked in manufacturing. Further, the CPS data is based on retrospective reporting for an entire year by a person who may be a surrogate respondent. Moreover, prior to 1976, the annual measure of hours is 1 imited to persons at work in the survey week, and as a result, for this period recent entrants and exits are excluded from the CPS measure. For these reasons, the CPS data may be more useful for measuring the distribution rather than the level of hours.

Third, the CPS data by industry are consistent with the BEA capital stock data in that employment at central administrative offices and auxiliaries is included; by contrast, the BLS employment data by industry based on the Census and Annual Survey of Manufactures includes employment only at production establishments, and excludes employees at the central administrative offices and auxiliaries.

Fourth, the Census and ASM data are based on monthly payroll records at production establishments, and therefore consist essentially of a count of the hours paid for a set of jobs, rather than hours actually at work. Moreover, it is widely believed that reporting error is likely to be less severe in the Census-ASM data than in the CPS.

The dilemma we therefore face in choosing how best to employ these data is the extent to which the advantages of the CPS data in terms of detail on occupation and educational attainment are offset by the unreliability of the 
measure of total level of hours. As a compromise, we therefore use other BLS sources to obtain measures of the total level of hours (more on this below), but utilize the CPS data to compute the distribution of hours by occupation and level of educational attainment.

The final set of data used in this paper is the output and input price and quantity data by two-digit manufacturing industry from 1952 to 1986 , provided us by Michael Harper of the US Bureau of Labor Statistics. The data series on gross output $Y$, aggregate labor $L$ (where hours are computed as a simple sum of production and non-production worker hours), aggregate energy input $N$, and non-energy intermediate materlals $M$ were constructed by BLS personnel using data from the Census of Manufactures and the Annual Survey of Manufactures. 18 Recall from the above discussion that these $L, N$ and $M$ data refer only to inputs utilized at production establishments, and do not incorporate input usage at the central administrative offices and auxiliaries of manufacturing firms. While this difference might affect the $L, N$ and $M$ measures, presumably the firm's measure of output is not materially affected by excluding central administrative offices and auxiliaries.

Using tax and depreciation data series, BLS officials have also constructed annual rental price measures for the various types of capital equipment and structures. 19 We have modified their ex post rental price computations to obtain an ex ante measure by incorporating Moody's Baa corporate bond yield as the ex ante interest rate, and have set the capital gains term in the traditional Hall-Jorgenson rental price formulae to zero for each component of capital. 20 We then constructed a Divisia index separately for the rental prices $P_{E Q}, P_{S T}$ and $P_{O F}$, and the implicit Divisia quantity indexes for $E Q, S T$ and $O F$.

IIIb. DATA TRENDS

With this outline of data construction procedures in mind, we now turn to an overview of summary statistics and notable trends. We begin with the 
capital and investment data, to highlight the dramatic growth in office and information technology capital. As is seen in Table 1, from 1976 to 1986 aggregate capital intensity (computed as the simple sum of the three capital stock components, $K^{\prime}=E Q+S T+O F$, all divided by gross output $Y$, each in 1971\$) has risen in seventeen of the twenty industries, with the only decreases in intensity occuring in textiles, lumber \& wood and rubber. For total manufacturing, the increase from 1976 to 1986 has been about 25\%. Thus the predominant trend across industries is one of increasing aggregate capital intensity in the last decade.

The composition of net investment has also been changing over this time period, as is shown in the final six columns of Table 1 . In particular, from 1976 to 1986 the share of OF net investment in total EQ + ST + OF investment has increased dramatically - - by more than twenty percentage points -. in ten of the twenty industries. It has increased by more than ten percentage points in four industries, and has fallen slightly (by less than ten percentage points) in only four industries. For total manufacturing, it has risen from $25.3 \%$ in 1976 to $36.8 \%$ in 1986. By 1986, in some industries the of share of total investment is very large, e.g., 57\% in printing and publishing, $66 \%$ in clay and glass, and $77 \%$ in non-electric machinery. Over the same $1976-86$ time period, the share of non-OF equipment investment $E Q$ has been falling in most industries (in all but food, leather and rubber), while the structures share of investment has dropped in fourteen and risen in only six industries. Hence the dominant trend in the composition of net investment is one of increasing shares of OF investment, and decreasing shares of both EQ and ST investment. In brief, these data indicate quite clearly that in almost all US manufacturing industries, not only has the aggregate capital-output ratio risen implying enhanced capital intensity, but the share of office and 
information technology equipment in total investmentl has also increased dramatically since 1968 .

We now turn to the labor data, where aggregate labor $L$ is the simple sum of hours for white collar (non-production) plus blue collar (productiona) worker hours taken from the BLS Harper data, i.e., L $=W+B$. In the first three columns of Table 2, we present average annual growth rates (AAGR's) over the 1968-86 time period by industry for $L, W$ and $B$. A number of results are particularly striking.

First, in twelve of twenty industries, the growth in total hours $L$ has been negative from 1968 to 1986; further, in sixteen of the industries, the growth in $B$ hours has been less (or, the decline has been greater) than that for W workers. For manufacturing in total, the AAGR of $L$ is $-0.18 \%$, that for $B$ hours is $-0.71 \%$, but that for $W$ hours is $0.92 \%$. Hence hours of W workers have been increasing at an AAGR of $1.63 \%$ more rapidly than that of $B$ workers. Second, as is seen in the middle columns of Table 2, the predominant pattern of simple correlations between $W-L$ and between $B-L$ is positive, consistent with mutual up- or down-scaling of hours for $B$ and W workers, but in four industries (food, tobacco, paper and miscellaneous manufacturing) the correlation between $W$ and $L$ is negative (in all but food, $W$ hours increased even as B hours decreased).

Third, the final columns of Table 2 indicate that aggregate labor intensity (L/Y, where $Y$ is gross output in 1971\$) has fallen in each of the twenty industries, varying from an AAGR of $-0.76 \%$ in fabricated metals, to a dramatic $-4.04 \%$ in non-electric machinery; for total manufacturing, the reduction has been $2.08 \%$ per year. Since the traditional definition of average labor productivicy $\mathrm{Y} / \mathrm{L}$ is simply the inverse of labor intensity $\mathrm{L} / \mathrm{Y}$, it follows that from 1968 to 1986, labor productivity grew in all twenty 
manufacturing industries, and for total manufacturing, it grew at an AAGR slightly greater than $2 \%$.

In Table 3 we report changes over time in the occupational composition of hours by industry. As is seen in the first four columns of Table 3 , in most (16 of 20) industries there has been an increase over time in the share of white collar (non-production) labor in total labor hours, consistent with relative growth rates presented in Table 2. Particularly large share increases have occurred in the tobacco, non-electric machinery, and electric machinery industries. For total manufacturing, the share of $W$ in total $L$ hours has increased from $29.4 \%$ in 1968 to $35.8 \%$ in 1986 - an AAGR of $1.10 \%$. The final five columns of Table 3 display the corresponding decreases over time in the share of blue collar (production) labor in most industries. Since $B$ plus $W$ shares must always sum to unity, the trends for B are simply the reverse of those for $W$, and thus we do not discuss them further here. Earlier we noted that the literature to date has offered conflicting hypotheses on the effects of increased office and information technology capital formation on the skill-composition of work forces, with some analysts conjecturing deskilling and others upgrading. The share trends observed in our data highlight some suggestive results regarding these questions. In Table 4 we present shares of white collar (non-production) labor by level of educational attainment, and in Table 5 we exhibit corresponding shares for blue collar (production) labor. In both tables, data are given for the years 1976 and 1986, since most of the increase in of capital formation occurred in the last ten years of our sample.

As is seen in Table 4, for white collar workers the share of hours provided by workers not having a high school diploma (NHS) declined from 1976 to 1986 in all industries but three - l lumber \& wood, leather, and miscellaneous manufacturing. For manufacturing in total, the NHS share 
dropped from $7.1 \%$ to $3.9 \%$. Shares for workers having a high school diploma (HS) also declined in all but three industries (textiles, petroleum refining and primary metals), and for total manufacturing, this share dropped from $38.7 \%$ to $31.8 \%$. Changes over time in the share of white collar hours provided by workers with some college (SC) were more evenly divided - - the share increased in ten industries and decreased in ten industries. For manufacturing in total, the share increased slightly from $22.8 \%$ to $23.3 \%$. However, in all but two industries (tobacco and primary metals), the share of white collar hours provided by workers with college degrees (C) increased from 1976 to 1986, often substantially; for manufacturing in total, the share jumped from $31.4 \%$ in 1976 to $41.0 \%$ in 1986.

Together with the data exhibited in Tables 2 and 3 , the picture that emerges from Table 4 is that white collar hours have in most cases been growing more rapidly than blue collar hours, and within the white collar occupations, there has been a definite increase in the share of hours provided by the more highly educated workers. In brief, this data analysis suggests that since 1986 skill upgrading has occurred within the white collar occupational categories. Whether these trends are correlated with increases in of capital formation across industries remains to be seen.

For blue collar workers, most of the movement in shares by education level occurs at the lower end of the educational attainnent measure. This is seen in Table 5. The proportion of blue collar hours provided by NHS workexs from 1976 to 1986 drops in all twenty industries, often considerably; for manufacturing in total, the decrease is from $43.0 \%$ in 1976 to $30.2 \%$ in 1986 . Shares of total blue collar hours provided by HS workers rose in all industries but one (miscellaneous manufacturing), and for manufacturing in total the increase is from $45.8 \%$ in 1976 to $52.8 \%$ in 1986 . Shares of SC workers also increased in all industries but one (the only decrease is in 
leather). By 1986, the share of blue collar hours provided by SC workers in total manufacturing is $12.8 \%$, up from $9.1 \%$ in 1976. Finally, the share of blue collar hours provided by $C$ workers increased in all but three industries (lumber \& wood, petroleum, and rubber), but by 1986 this share was still relatively small - - for total manufacturing, only $4.2 \%$ in 1986 , compared to $2.1 \%$ in 1976 .

In summary, for blue collar workers, since 1976 the major change has been a rather sharp drop in the hours provided by NHS workers; this decrease has been offset primarily by an increase in the share contributed by HS workers, although there have also been modest increases in the shares provided by SC and $C$ workers. Not unexpectedly, what upgrading that has occurred for blue collar workers is primarily from the NHS to HS diploma categories. With these data trends in mind, we now move on to a discussion of results obtained from regression analysis, in which we can more directly relate labor productivity, and labor demand by occupation and educational attainment, to overall capital intensity and changes in its composition. We first focus on the relationship between high-tech capital and aggregate labor intensity, and then analyze effects on the composition of aggregate labor hours.

\section{REGRESSION ANALYSIS}

A. HIGH-TECH CAPITAL AND AGGREGATE LABOR INTENSITY

The approach taken in this paper is one of exploratory data analysis and multiple regression, and in particular here we do not utilize a highly structured econometric model; a more rigorous econometric approach is taken in, for example, Morrison and Berndt [1990]. Nonetheless, it is useful to provide some discussion here on the rationale underlying the choice of explanatory variables used in the regression analysis. 
HIGH-TECH CAPITAL FORMATION AND LABOR COMPOSITION

In the regressions with aggregate labor intensity $(\ln (L / Y)=L N L Y)$ as the dependent variable, considerations from the economic theory of cost and production suggest that a measure of capital intensity be included as a regressor to reflect possible capital-labor substitutability. If the underlying production function were Cobb-Douglas with constant returns to scale imposed, for example, then the regression equation could be of the form $\operatorname{LNLY}=\alpha+\beta_{1} \ln (\mathrm{K} / \mathrm{Y})$

where $K$ is an aggregate of the three types of capital used in this study - OF (office and information technology capital equipment), EQ (all other non-OF capital equipment) and ST (non-residential structures).

Now if these three types of capital were equally productive per dollar of services, then the composition of aggregate capital would have no impact on labor intensity. Hence in an expanded regression equation of the form

$$
L N L Y=\alpha+\beta_{1} \ln (K / Y)+\beta_{2} \ln (O F / K)+\beta_{3} \ln (E Q / K)
$$

if the various types of capital were equally productive, then we would expect $\beta_{2}=\beta_{3}=0$. On the other hand, if of capital were more productive per dollar of services than $E Q$ or $S T$ capital, for example, then the composition of capital would matter; in this case we would expect $\beta_{2}<0$, for increases in the OF composition of capital would, ceteris paribus, result in reduced labor intensity (enhanced labor productivity). Finally, if of capital were less productive per dollar of services than EQ or ST capital, then $\beta_{2}>0$, and increases in the OF share of capital would, ceteris paribus, increase labor intensity and decrease labor productivity.

A time counter variable, $t$, is also added as a regressor to Eq. (2). This has at least two interpretations. First, if the supply of labor (and/or its various components by occupation and level of educational attainment) is gradually increasing over time due to demographic shifts, then the $t$ variable 
will reflect such movements over time. Second, if technological progress occurs at a relatively constant rate over time, then this too would be captured by including $t$ as a regressor.

Hence the first equation we estimate is

$$
\mathrm{LNLY}=\alpha+\beta_{1} \ln (\mathrm{K} / \mathrm{Y})+\beta_{2} \ln (\mathrm{OF} / \mathrm{K})+\beta_{3} \ln (\mathrm{EQ} / \mathrm{K})+\beta_{4} \mathrm{t}+\mathrm{u}
$$

where $u$ is a stochastic disturbance term with traditional i.i.d. properties. 21 The parameters of equation (3) were estimated (i) separately by industry ("within" regressions); (ii) incorporating cross-section variability by pooling the cross-section and time series data, assuming that slope coefficients are equal across industries but intercepts are not ("pooled" regressions); (iii) by simply summing the data across industries to the total manufacturing level and then estimating Eq. (3) using the aggregated data ("aggregate" regressions). 22

In Table 6 we present results of the twenty separate within industry regressions. In only one of the twenty industries (chemicals) is the coefficient on $\ln (\mathrm{OF} / \mathrm{K})$ negative; in 19 of the 20 industries it is positive, and significantly so in six of these 19. This implies that, ceteris paribus, for the within-industry regressions increases in the share of high-tech capital $O F / K$ are predominantly positively correlated with labor intensity, and therefore are typically negatively correlated with average labor productivity. 23 It is also worth noting that the sign of the estimated coefficient on $\ln (E Q / K)$ is mixed, being evenly divided between negative and positive in the twenty industries. However, the coefficient on $t$ is negative in all industries, reflecting perhaps the effects of technological progress in reducing labor intensity.

When cross-sectional variation is incorporated into the analysis by estimating a pooled cross-section, time series model, the finding that 
increases in $\ln (O F / K)$ are positively (negatively) correlated with aggregate labor intensity (average labor productivity) persists:

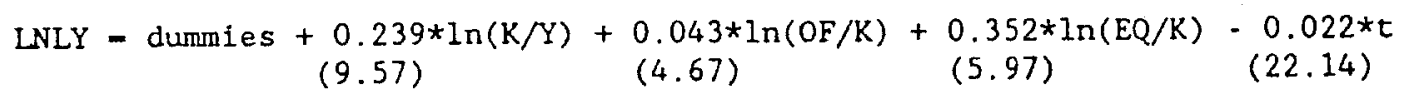

with an $R^{2}$ of 0.981 . The coefficient on $\ln (E Q / K)$ is positive and even larger than that on $\ln (O F / K)$, and the coefficient on $\ln (K / Y)$ is also positive, consistent with the predominant trend in the within-industry regressions of Table 6 .

Moreover, when the underlying data are summed to the total manufacturing level, the time series regression results are as follows:

$$
\begin{aligned}
& \text { LNLY }=-1.752-0.174 * \ln (\mathrm{K} / \mathrm{Y})+0.107 * \ln (\mathrm{OF} / \mathrm{K})-0.849 * \ln (\mathrm{EQ} / \mathrm{K})-0.035 * \mathrm{t} \\
& \begin{array}{llll}
(1.73)(2.12) & (2.15) \quad(1.69) & (10.02)
\end{array}
\end{aligned}
$$

with an $\mathrm{R}^{2}$ of 0.983 and a Durbin-Watson test statistic of 1.432 . Again, in this total manufacturing equation, the coefficient on $\ln (O F / K)$ remains positive and statistically significant, although that on $K / Y$ becomes negative, consistent with aggregate K-L substitutability.

We conclude, therefore, that based on these aggregate labor intensity regressions, the rapid accumulation of high-tech office and automation equipment capital has not been labor-saving, but instead is correlated with increases in labor intensity and decreases in average labor productivity. Moreover, this finding is reasonably robust among the various time series and pooled cross-section, time series regressions. 24

We now turn to an examination of the occupational composition of workers in US manufacturing industries, and assess how labor productivity changes vary by occupation and skill. Recall that according to Griliches' capital-skill complementarity hypothesis, ceteris paribus, one would expect a positive relationship between $\ln (\mathrm{K} / \mathrm{Y})$ and $\ln (\mathrm{W} / \mathrm{Y})$. In Table 7 we present withinindustry regressions where $\operatorname{LNWY}(\ln (\mathrm{W} / \mathrm{Y})$, the logarithm of the ratio of white collar, non-production worker hours to gross output) is the dependent 
HIGH-TECH CAPITAL FORMATION AND LABOR COMPOSITION variable. Not only is the coefficient on $\ln (K / Y)$ positive in 11 of 20 industries - consistent with Griliches' capital-skill complementarity hypothesis - but the coefficient on the high-tech capital composition variable $\ln (O F / K)$ is also positive in 13 of 20 industries.

These capital-skill findings are again obtained when pooled crosssection, time series data are employed:

$$
\mathrm{LNWY}=\text { dummies }+\underset{(5.79)}{0.383 * \ln (\mathrm{K} / \mathrm{Y})}+\underset{(3.06)}{0.075 * \ln (\mathrm{OF} / \mathrm{K})}+\underset{(1.59)}{0.249 * \ln (\mathrm{EQ} / \mathrm{K})}-\underset{(4.88)}{0.013 * t}
$$

with an $\mathrm{R}^{2}$ of 0.914 . Note that the positive estimated coefficient on $\ln (\mathrm{OF} / \mathrm{K})$ is statistically significant at typical confidence levels.

When the data are summed to the total manufacturing level of aggregation, we obtain the equation

$$
\begin{array}{cccc}
\text { LNWY }=-9.422-0.372 * \ln (K / Y)+ & 0.141 * \ln (\mathrm{OF} / \mathrm{K}) & -4.856 * \ln (\mathrm{EQ} / \mathrm{K}) & -0.049 * t \\
(1.70) & (0.83) & (0.52) & (1.77)
\end{array}
$$
(1.70)
$(0.52)$
$(1.77)$

with an $R^{2}$ of 0.449 and a Durbin-Watson test statistic of 2.40 . Relative to the pooled regression, in this total manufacturing equation the coefficient on $\ln (K / Y)$ becomes negative, but the effect of high-tech capital composition $\ln (O F / K)$ increases and is larger in absolute value than the coefficient on $\ln (\mathrm{K} / \mathrm{Y})$. These findings suggest a high-tech capital-skill complementarity relationship, rather than an aggregate capital-skill complementarity notion.

In Table 8 we present analogous regression results when the dependent variable is LNBY - the logarithm of the ratio of blue collar, production worker hours to gross output. The results indicate a positive estimated coefficient on aggregate capital intensity $\mathrm{K} / \mathrm{Y}$ in 11 of 20 industries, which is statistically significant in only one industry (apparel). The estimated coefficient on $\ln (O F / K)$ is positive again in 12 industries, and is significantly so in four of them. Signs of the estimated $\ln (E Q / K)$ parameters are more evenly divided -. 9 negative and 11 positive, but the time coefficient is predominantly negative (18 of 20 industries). 
HIGH-TECH CAPITAL FORMATION AND LABOR COMPOSITION

Interesting results emerge when one employs the pooled cross-sectional,

time series data:

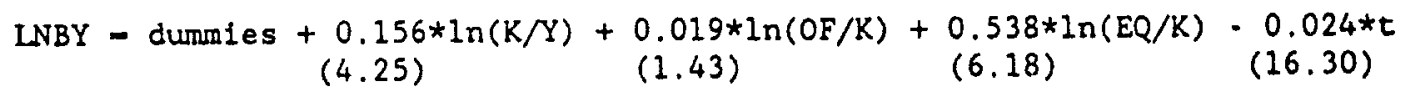

with an $R^{2}$ of 0.971 . Notice that the coefficient on $\ln (O F / K)$ is positive but Insignificant, while that on $\ln (K / Y)$ is positive and significant (although smaller than the estimates reported above for the white-collar regressions).

When data are summed to the aggregate manufacturing level, rather different findings appear:

LNBY $=1.409 \cdot 0.107 * \ln (K / Y)+0.128 * \ln (O F / K)+1.252 * \ln (E Q / K) \cdot 0.031 * t$
$(0.73) \quad(0.69)$
(1.35)
(1.31)
$(4.57)$

with an $R^{2}$ of 0.758 and a Durbin-Watson test statistic of 1.643 . Here, aggregate capital is substitutable with blue-collar, production labor, but increases in the high-tech office automation and information technology equipment composition of capital increase blue-collar labor intensity, although this latter effect is not statistically significant.

We conclude, therefore, that while the evidence on positive correlations between $O F / K$ and white collar labor intensity is reasonably consistent, that between $O F / K$ and blue collar labor intensity is more mixed and less significant statistically; moreover, variations among industrles are substantial.

IVb. HIGH-TECH CAPITAL AND THE DESKILIING VS. SKILL UPGRADING HYPOTHESES

Recall that in our brief literature review we noted the controversy that exists between those arguing that office and information technology capital results in a deskilling of the work force vs. those alleging that upgrading occurs instead. The deskilling-upgrading controversy involves changes in the skill composition both within and between occupational classes. Although in the previous sub-section we presented results relating changes in the ratios of $W / Y$ and $B / Y$ to high-tech and other capital variables, it is of interest in 
the context of this controversy to examine interoccupational composition changes more directly. Hence we now investigate changes in relative proportions of employment hours between and within the blue collar and white collar occupations. To conserve space we will not report here the detailed within-industry results on these issues. A number of interesting results and non-results emerge, however, from the pooled cross-section, time series regressions.

Define the share of white collar (non-production) worker hours in total white plus blue collar hours $(W / L)$ as $W L$, and the corresponding blue collar share $(B / L)$ as $B L$, where $W L+B L=1.0$. We have regressed the WL share on the same set of explanatory variables as above (an industry-specific constant, $\ln (K / Y), \ln (O F / K), \ln (E Q / K)$, and a time trend), using the pooled crosssection, time series data. Since the two shares sum to unity at each observation, the slope coefficients on the WL equation are simply the negative of those on the BL equation.

Hence, due to the share-based specification, if a regressor affects the Wh share positively, by definition it must affect the BL share negatively. If a regressor has an equi-proportional effect on levels and therefore a neutral impact on shares, the coefficient will be zero, but if a regressor has a biased impact, the coefficient will be non-zero. Thus, consistent with the literature on technical change and other biases, the sign of any estimated slope coefficient reveals the biased impact (saving vs. using) of that regressor on employment composition. 25 This provides evidence on the relative shifts of $W$ as compared to $B$, in contrast to the changes in levels considered above.

OLS estimates for the WL equation turn out to be

$$
\begin{aligned}
& \mathrm{WL}=\text { dummies }+0.054 \cdot \ln (\mathrm{K} / \mathrm{Y})+0.014 \cdot \ln (\mathrm{OF} / \mathrm{K}) \cdot 0.091 \cdot \ln (E Q / K)+0.002 \cdot t \\
& (3.37) \quad(2.32) \quad(2.41)
\end{aligned}
$$


with an $R^{2}$ of 0.907 . Notice that each of the estimated coefficients in this equation is statistically significant. 26 These results are quite striking, and imply that increases in aggregate capital intensity, and in the high-tech composition of capital, are each correlated with interoccupational shifts toward white collar employment. Variations in $K / Y$ and $O F / K$ are biased toward white collar hours ( $W$-using), whereas $E Q / K$ increases are biased toward blue collar employment (B-using); the positive time trend term also indicates a time bias toward white collar hours. Since white collar workers on average have a higher educational attainment, one could also interpret these results as supporting the notion that OF capital accumulation is correlated with interoccupational skill upgrading.

However, as we noted earlier, much of the deskilling-upgrading controversy concerns intraoccupational changes. Within the blue collar, production worker occupations, we can address this issue using the hours data disaggregated by four levels of educational attainment - no high school (NHS), high school diploma (HS), some college (SC), college degree (C); call the share of hours for each of these four types of educational attainment groups relative to total blue collar hours BNHSB (BNHS/B), BHSB (BHS/B), BSCB $(B S C / B)$, and $B C B(B C / B)$. In our estimated equations, we relate these blue collar employment shares by educational attainment to the same set of regressors as above.

With these share equations, again the sum of the biases is zero, which means that for each regressor the sum of the share effects (coefficient estimates) over all Eour educational share classes is zero. If a regressor affects all four educational classes by the same proportional amount, this regressor has a neutral impact on shares, and its coefficient will be zero in each share equation. If, however, a regressor affects one educational class by a greater positive proportional amount than the average proportional impact 
HICH-TECH CAPITAL FORMATION AND LABOR COMPOSITION

on all educational classes, then its coefficient will be positive, indicating a biased (-using) impact. Hence, again, the coefflclent estimates and biases can be interpreted as reflecting relative rather than absolute impacts on the four educational clesses.

Based on the pooled cross-section, time series data, we have estimated these four share equations by ordinary least squares. 27 The results obtained are as follows: 28

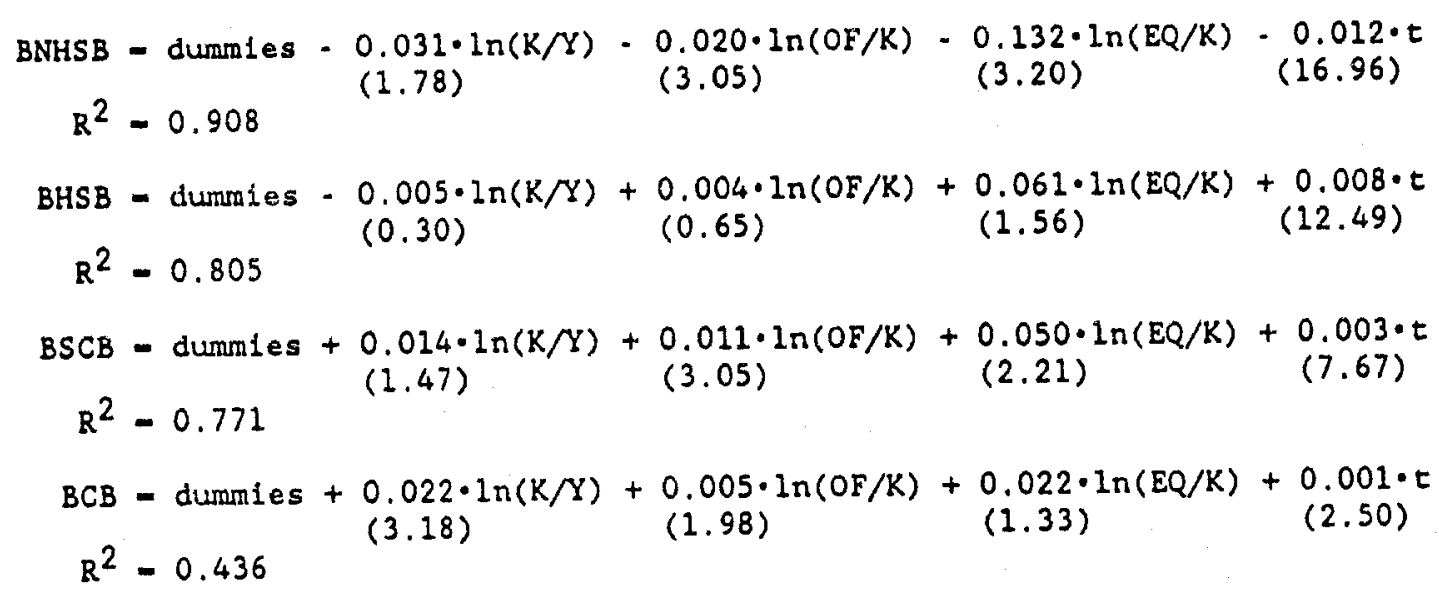

Several comments are worth noting. First, each time trend coefficlent is highly significant .. negative for no high school, but positive for the three other educational attainment levels. Given the trends in blue collar hours displayed in Table 5, these time trend results are not surprising. Second, a substantial number of the coefficients are statistically significant, including most of the negative coefficients in the BNHSB equation, as well as the $E Q / K$ coefficient in the $B S C B$ equation, and the aggregate $K / Y$ coefficient in the $B C B$ share equation.

A rather striking result, however, concerns the relative size of the $\ln (\mathrm{K} / \mathrm{Y})$ coefficients, which increase monotonically with educational attainment, rising from -0.031 (NHS) to $0.022(\mathrm{C})$. Increasing capital intensity has a systematic biased impact on employment shares of blue collar workers, imposing the highest costs in terms of relative employment decines on NHS 
workers. Workers with a HS diploma also are hurt relative to those with more education, for the $\ln (K / Y)$ coefficient in the HS share equation is negative, but not as large (in absolute value) as in the NHS share equation. Employment for workers with some college increases relative to the average along with increases in $\ln (\mathrm{K} / \mathrm{Y})$, but those with a college education benefit the most, for the coefficient on $\ln (K / Y)$ in the $B C B$ equation is positive, largest, and most significant.

Similarly, when OF/K increases, ceteris paribus, blue collar workers without a high school diploma suffer relative employment declines; the coefficient estimate of -0.020 is negative and statistically significant. Workers with more education benefit relative to those with less, as with capital deepening, although the largest and most significant of effect occurs for those with some college education.

We conclude, therefore, that within the blue collar, production worker occupations, skill upgrading has occurred along with increases in the hightech composition of capital. This appears to have been most pronounced for NHS workers, whose relative hours have been most clearly reduced. Skill upgrading is quite pervasive, however, with a distinct trend moving toward more highly educated workers as increases in OF/K take place.

For the white collar occupations, the dependent variables corresponding to shares of hours by each of the four educational attainment levels are WNHSW (WNHS $/ W$ ), WHSW (WHS $/ W)$, WSCW (WSC/W) and WCW (WC/W). Parameter estimates based on pooled cross-section, time series regressions are as follows:

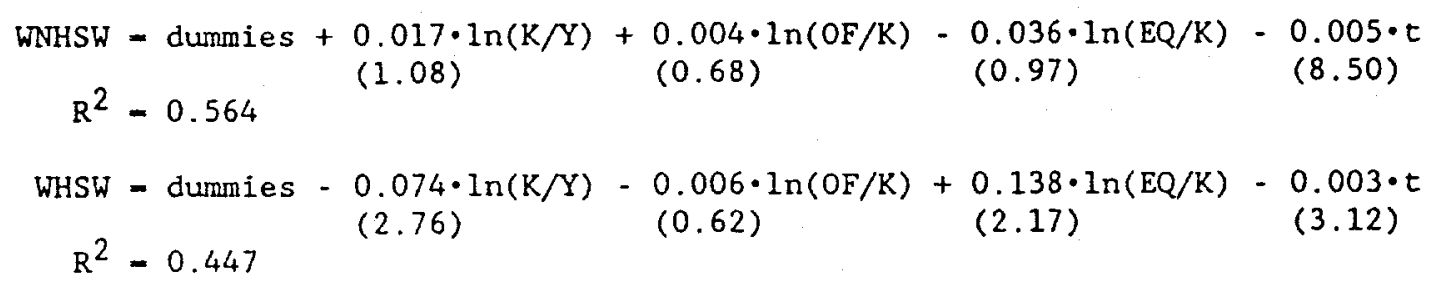


HIGH-TECH CAPITAL FORMATION AND LABOR COMPOSITION

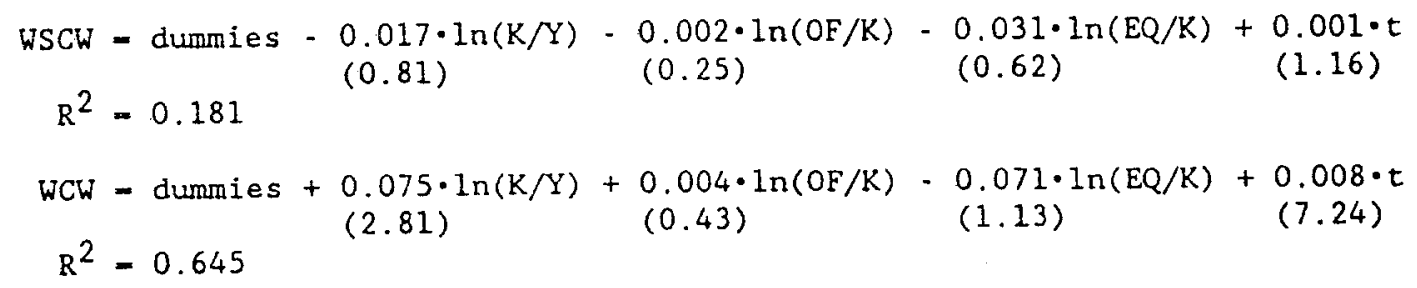

\section{Notice that the time trend terms are negative in the NHS and HS}

equations, are positive in the $\mathrm{SC}$ and $\mathrm{C}$ equations, and increase monotonically with education level. Moreover, for each of the regressors the coefficients follow a monotonic trend with education above the NHS level. An interesting result for $W$ is that in none of the equations is the coefficient on the $\ln (O F / K)$ high-tech capital composition variable statistically significant, although coefficients on the capital deepening variable $\ln (\mathrm{K} / \mathrm{Y})$ have a clearer trend and two are statistically significant.

For both types of capital effects $(K / Y$ and $O F / K)$, point estimates of biases indicate that HS and SC workers appear to be hurt in terms of employment relative to those with the least (NHS) or the most (C) education, although six of the eight $K / Y$ and $O F / K$ bias coefficients are each insignificantly different from zero. Hence, while deskilling and upgrading of white collar occupations may be occurring simultaneously within US manufacturing industries along with increases in the share of high-tech office automation and information technology equipment, for the most part the net effects are apparently insignificantly different from zero.

\section{SUMMARY AND CONCLUDING REMARKS}

our purpose in this paper has been to report results from an exploratory effort examining empirical relationships among investments in high-tech office and information technology capital and the distribution of employment by occupation and level of educational attainment.

Based on 1968-86 annual data for twenty two-digit US manufacturing 
industries, we have estimated parameters in within-industry regressions, in pooled cross-section, time series regressions, and in equations using data summed to the total manufacturing level of aggregation. Our regression results can be sumarized as follows.

The relationship between aggregate labor productivity and high-tech capital was examined by estimating equations in which the dependent variable was the logarithm of aggregate labor intensity $-\ln (L / Y)$, which is the inverse of average labor productivity. Here we obtained the somewhat striking result that changes in $O F / K$ are positively correlated with $L / Y$, and are therefore negatively correlated with average labor productivity. Hence, in this sense, rather than being labor-saving, ceteris paribus, increases in $O F / K$ tend to be labor-using. This rather provocative finding is quite robust, occurring in the within-industry, total manufacturing, and pooled regressions. 29

In terms of the occupational composition of the work force, our predominant finding is that increases in $O F / K$ high-tech capital composition are positively related to growth in hours provided by white collar, nonproduction workers, consistent with Griliches' capital-skill complementarity hypothesis. However, while the evidence on positive correlations between OF/K and white collar labor intensity is reasonably consistent and statistically significant, that between $O F / K$ and blue collar, production worker hours is more mixed and less significant.

Finally, in terms of the effects of of capital accumulation on the skill composition of the work force in US manufacturing industries, we find clear evidence in support of interoccupational skill upgrading from blue collar to white collar hours as $O F / K$ increases. Within the blue collar occupations, skill upgrading is quite pervasive, with a distinct trend moving toward more highly educated workers as increases occur in the high-tech composition of 
capital. This is quite pronounced for NHS workers, whose relative hours have been most clearly reduced. Within the white collar occupations, although deskilling and upgrading may have been occurring simultaneously, we find that the net effects of changes in the $O F / K$ high-tech capital composition on changes in the share of hours provided by workers having no high school diploma, high school, some college or a college degree are each insignificantly different from zero. However, point estimates suggest that workers having either NHS or C fare relatively better than those with HS or SC.

It is worth emphasizing that our methodology in this paper has been one of data analysis, rather than one using detalled structural models. It is possible that a more structural approach would yield results qualitatively different from those reported here. However, we are somewhat skeptical of this, at least in terms of labor productivity, given the evidence presented in Morrison and Berndt [1991]. These results, based on a highly structured model, indicate that by 1986 most two-digit manufacturing industries had overinvested in OF capital in the sense that marginal benefits of $O F$ investment had begun to fall short of marginal costs. Hence, those findings are supportive of the themes emerging from this research. 


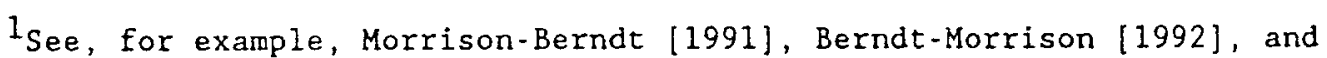
Brynjolfsson [1991], and the references cited therein.

${ }^{2}$ For an exploratory analysis involving managers and clerks, see Paul R. Osterman [1986].

${ }^{3}$ Griliches [1988, p. 11]; also see Griliches [1970].

${ }^{4}$ Also see Jonathan R. Kesselman et al. [1977]. In his survey, Daniel S. Hamermesh [1986] reports that almost all the evidence to date supports Griliches' capital-skill complementarity hypothesis.

${ }^{5}$ On this, also see Jacob Mincer [1989] and Steve Davis and John Haltiwanger [1991].

${ }^{6}$ Also see Finis R. Welsh [1970], who argues that better educated workers have a comparative advantage in adopting such new technologies.

7 Also see Steven G. Allen [1991], Michael A. Boozer et al. [1991], and Jacob Mincer [1989].

${ }^{8}$ For a survey and critique, see Paul Attewell [1987].

${ }^{9}$ See, for example, Daniel Bell [1963], and Enid Mumford and Olive Banks [1967].

${ }^{10}$ See the citations in Attewell [1987].

${ }^{11}$ On this, see Kevin Crowston and Thomas Malone [1988].

12 For a discussion of issues, see, for example, Paul Attewe11 [1990].

${ }^{13}$ See, for example, Kenneth Spenner [1985], and David R. Howell and Edward Wolff $[1990,1991]$.

14 Howell and Wolff [1991] report that in their data, the simple correlations between measures of cognitive abilities and educational attainment are positive and significant, but considerably less than perfect.

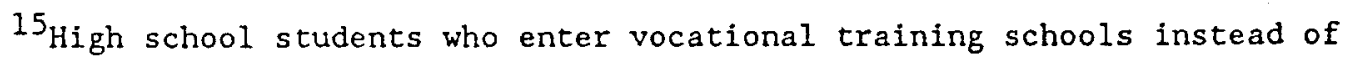
obtaining a high school diplona are counted as "no high school".

${ }^{16} \mathrm{~A}$ useful discussion of difficulties in obtaining meaningful and timeconsistent measures of employment by occupation is found in $\mathrm{H}$. Allan Hunt and Timothy L. Hunt [1986]; also see Kenneth I. Spenner [1985].

17 Although the sample size of the March survey varies from year to year, on average it surveys about 50,000 households.

${ }^{18}$ To compute the distribution of employment by educational attainnent and occupation, we multiplied the Harper total I data by the shares of total hours based on the CPS data.

${ }^{19}$ Discussion of rental price construction methods and references to 
appropriate BLS publications are found in Harper et al. [1989].

20 In the BLS data base, the depreciation rates for each asset follow a hyperbolic pattern and are not necessarily constant over time; depreciation rates for the $E Q, S T$ and $O F$ composites also vary across industries and time due to changes in the composition of the stocks. In fact, however, the depreciation rates tend to be very stable over time for each asset. For 1986, the capital stock-weighted average depreciation rates for EQ in the machinery, chemicals and iron and steel industries are approximately 6,8 and $6 \%$, respectively, for ST they are all about $4 \%$, and for OF the weighted-average depreciation rates for these three industries are 17,15 and $14 x$, respectively.

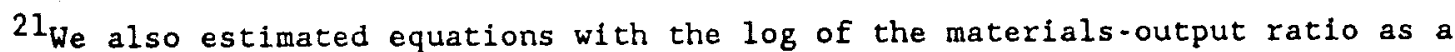
regressor. Although point estimates of parameters were affected, none of the qualitative findings we report in this paper are altered by inclusion of the In(M/Y) variable. See Berndt-Morrison [1992] for further details.

22 Results of regressions using a linear rather than a $\log -10 \mathrm{~g}$ functional form are available from the authors upon request. These regressions give esslentially similar qualitative results.

${ }^{23}$ Notice also that according to the Cobb-Douglas model (4), substitutability between capital and labor implies that $\alpha_{2}$ (the coefficient on $\ln (K / Y$ ) in (4)) should be negative; in the within industry regressions of Table 6 , however, this coefficient is positive in 14 of the 20 industries, and in six of them, it is statistically significant. Hence there is a problem in trying to give these regression estimates a structural interpretation.

${ }^{24}$ For further analysis of this somewhat unexpected finding, see Berndt and Morrison [1992].

${ }^{25}$ This is analogous to the standard definition of technical change biases; see, for example, Hans P. Binswanger [1974].

26 Interestingly, in the within industry regressions, very few slope coefficients were statistically significant, nor were they significant in the total manufacturing regression.

27 Similar qualitative findings were obtained when the $10 \mathrm{~g}$ of the intermediate materials input/gross output variable was added as a regressor.

28 To conserve on space, we do not report industry-specific results. These are available from the authors upon request.

${ }^{29}$ Though not reported in this paper, this finding also occurs when levels of employment, rather than labor input-output coefficients, are the dependent variable, and when in $Y$ is added as a regressor. It also remains when once and twice-lagged values of gross investment in of capital are included, to capture possible lagged effects due to learning. For further discussion, see Berndt and Morrison [1992]. 
Table 1

CAPITAL INTENSITY AND INVESTMENT COMPOSITION, U.S. MANUFACTURING

\begin{tabular}{|c|c|c|c|c|c|c|c|c|}
\hline \multirow[b]{3}{*}{ Industry } & \multirow{2}{*}{\multicolumn{2}{|c|}{$\begin{array}{l}\text { Aggregate } K^{\prime} \\
\text { Intensity }\end{array}$}} & & $\mathrm{Ne}$ & \multicolumn{4}{|c|}{ Investment Shares ( $(x)$} \\
\hline & & & & & & & & \\
\hline & 1976 & 1986 & $\underline{1976}$ & 1986 & 1976 & 1986 & 1976 & $\underline{1986}$ \\
\hline Food & .743 & .788 & 46.7 & 48.6 & 31.6 & 29.2 & 21.6 & 22.3 \\
\hline Tobacco & .608 & 1.571 & 58.4 & 42.9 & 24.7 & 24.9 & 16.9 & 32.2 \\
\hline Textiles & 1.454 & 1.279 & 61.1 & 56.7 & 33.6 & 26.7 & 5.3 & 16.6 \\
\hline Appare 1 & .424 & .432 & 47.8 & 23.2 & 37.3 & 41.2 & 14.9 & 35.7 \\
\hline $\begin{array}{l}\text { Lumber } \\
\& \text { Wood }\end{array}$ & 1.491 & 1.206 & 73.3 & 50.4 & 24.0 & 34.1 & 2.7 & 15.5 \\
\hline $\begin{array}{l}\text { Furniture } \\
\text { \& Fixture }\end{array}$ & .676 & .775 & 29.8 & 25.3 & 52.3 & 25.3 & 18.0 & 49.5 \\
\hline Paper & 2.001 & 2.176 & 73.0 & 57.4 & 17.2 & 13.6 & 9.8 & 29.1 \\
\hline $\begin{array}{l}\text { Printing } \\
\text { \& Publish }\end{array}$ & 1.040 & 1.426 & 44.9 & 28.3 & 28.3 & 14.5 & 26.8 & 57.2 \\
\hline Chemicals & 2.371 & 2.490 & 39.8 & 37.8 & 15.8 & 24.1 & 44.4 & 38.1 \\
\hline Petroleum & 1.613 & 2.167 & 45.0 & 39.0 & 38.6 & 44.8 & 16.4 & 16.3 \\
\hline Rubber & 1.368 & 1.109 & 69.4 & 72.4 & 26.7 & 24.5 & 3.9 & 3.1 \\
\hline Leather & .554 & .860 & 49.0 & 50.4 & 54.3 & 47.1 & -3.3 & 2.5 \\
\hline $\begin{array}{l}\text { Clay } \\
\& \text { Glass }\end{array}$ & 2.002 & 2.891 & 51.2 & 20.7 & 17.8 & 13.4 & 31.0 & 66.0 \\
\hline $\begin{array}{l}\text { Primary } \\
\text { Metals }\end{array}$ & 2.353 & 3.387 & 61.5 & 60.3 & 18.0 & 22.4 & 20.4 & 17.3 \\
\hline $\begin{array}{l}\text { Fabricated } \\
\text { Metals }\end{array}$ & .975 & 1.247 & 68.3 & 54.9 & 26.3 & 17.6 & 5.4 & 27.5 \\
\hline Machinery & 1.080 & 1.819 & 35.6 & 15.1 & 22.1 & 7.7 & 42.3 & 77.2 \\
\hline $\begin{array}{l}\text { Electric } \\
\text { Machinery }\end{array}$ & 1.084 & 1.336 & 45.6 & 33.3 & 26.0 & 17.1 & 28.4 & 49.6 \\
\hline Instrument & .869 & 1.298 & 46.0 & 28.3 & 33.5 & 13.2 & 20.5 & 58.5 \\
\hline $\begin{array}{l}\text { Transporta } \\
\text { tion Equi }\end{array}$ & 1.035 & 1.260 & 64.6 & 45.9 & 21.2 & 19.1 & 14.2 & 35.1 \\
\hline Misc. Mfg. & .799 & 1.094 & 57.8 & 37.9 & 30.8 & 28.1 & 11.4 & 34.0 \\
\hline Total $\mathrm{Mf}_{\mathrm{g}}$. & 1.227 & 1.531 & 51.1 & 42.2 & 23.6 & 21.1 & 25.3 & 36.8 \\
\hline
\end{tabular}

Notes: The aggregate capital intensity $K^{\prime} / Y$ is computed as the simple sum of the three capital stock components (EQ, ST and OF) divided by gross output, all in $1971 \$$. 
Table 2

LABOR GROWTH RATES (1968-86, YAAGR), CORRELATIONS and LABOR-OUTPUT RATIOS

\begin{tabular}{|c|c|c|c|c|c|c|c|c|c|c|}
\hline \multirow[b]{2}{*}{ Industry } & \multirow[b]{2}{*}{ L } & \multicolumn{2}{|l|}{ AAGR } & \multicolumn{2}{|c|}{ Correlations } & \multicolumn{4}{|c|}{$\begin{array}{c}\text { Aggregate Labor Intensity } \\
\underline{L} / \mathrm{C}\end{array}$} & \multirow[b]{2}{*}{$\frac{A A G R}{x}$} \\
\hline & & $\underline{W}$ & $\underline{B}$ & $\underline{W}: \mathbf{L}$ & B:L & 1968 & $1976^{I}$ & 1981 & 1986 & \\
\hline Food & $-0.61 \%$ & -0.437 & $-0.81 \%$ & -.382 & .859 & .207 & .162 & .148 & .133 & $-2.43 x$ \\
\hline Tobacco & -2.01 & 3.59 & -3.79 & $\cdot .612$ & .927 & .143 & .118 & .112 & .109 & -1.50 \\
\hline Textiles & -1.88 & 0.54 & -2.37 & .248 & .984 & .502 & .355 & .306 & .262 & -3.55 \\
\hline Apparel & -1.16 & -0.62 & -1.26 & .424 & .928 & .468 & .390 & .343 & .312 & -2.23 \\
\hline $\begin{array}{l}\text { Lumber } \\
\& \text { Wood }\end{array}$ & 0.34 & 1.91 & 0.06 & .132 & .923 & .445 & .373 & .358 & .309 & -2.01 \\
\hline $\begin{array}{l}\text { Furniture } \\
\text { \& Fixtures }\end{array}$ & 0.61 & 0.44 & 0.66 & .348 & .915 & .433 & .345 & .312 & .311 & -1.82 \\
\hline Paper & -0.08 & 0.35 & -0.22 & -.249 & .773 & .420 & .341 & .304 & .258 & -2.67 \\
\hline $\begin{array}{l}\text { Printing } \\
\& \text { Publishing }\end{array}$ & 1.93 & 2.68 & 1.08 & .933 & .602 & .493 & .456 & .434 & .426 & -0.81 \\
\hline Chemicals & 0.01 & 0.61 & .0 .63 & .215 & .404 & .384 & .293 & .271 & .241 & -2.55 \\
\hline Petroleum & -0.38 & -1.45 & 0.86 & .263 & .563 & .112 & .095 & .109 & .084 & -1.59 \\
\hline Rubber & 1.94 & 1.22 & 2.16 & .741 & .945 & .408 & .359 & .356 & .313 & -1.46 \\
\hline Leather & -4.73 & -4.69 & -4.74 & .796 & .989 & .484 & .439 & .415 & .392 & -1.16 \\
\hline $\begin{array}{l}\text { Clay } \\
\& \text { Class }\end{array}$ & -0.39 & -0.81 & -0.24 & .188 & .948 & .421 & .381 & .379 & .352 & -0.99 \\
\hline $\begin{array}{l}\text { Primary } \\
\text { Metals }\end{array}$ & -2.81 & -1.85 & -3.06 & .649 & .989 & .389 & .348 & .326 & .319 & -1.10 \\
\hline $\begin{array}{l}\text { Fabricated } \\
\text { Metals }\end{array}$ & -0.76 & .0 .64 & -0.81 & .471 & .891 & .372 & .361 & .354 & .324 & -0.76 \\
\hline Machinery & 0.21 & 2.00 & -0.83 & .610 & .645 & .496 & .381 & .321 & .236 & .4 .04 \\
\hline $\begin{array}{l}\text { Electric } \\
\text { Machinery }\end{array}$ & 0.54 & 1.99 & -0.46 & .896 & .579 & .534 & .407 & .333 & .275 & -3.62 \\
\hline Instruments & 1.61 & 2.03 & 1.15 & .820 & .764 & .544 & .377 & .353 & .316 & -2.97 \\
\hline $\begin{array}{l}\text { Transporta- } \\
\text { tion Equipt }\end{array}$ & -0.38 & 0.42 & -0.78 & .549 & .821 & .420 & .316 & .350 & .294 & -1.96 \\
\hline Misc. Mfg. & -0.63 & 0.72 & -1.13 & -.165 & .885 & .424 & .348 & .332 & .346 & -1.12 \\
\hline Total $\mathrm{Mfg}_{\mathrm{g}}$ & -0.18 & 0.92 & -0.71 & .907 & .970 & .387 & .313 & .301 & .265 & -2.08 \\
\hline
\end{tabular}

Notes: AAGR denotes average annual growth rate. $L$ is the sum of production and nonproduction worker labor hours calculated by the BLS, using data from the Census and Annual Survey of Manufactures. $B$ and $W$ are production and nonproduction labor hours, constructed using labor composition shares based on the March Current Population Survey applied to the L data such that $W+B=L$. 
Table 3

COMPOSITION OF LABOR HOURS - WHITE AND BLUE COLIAR IABOR SHARES AND AAGR, U.S. MANUFACTURING INDUSTRIES

\begin{tabular}{|c|c|c|c|c|c|c|c|c|c|c|}
\hline \multirow[b]{2}{*}{ Industry } & \multicolumn{4}{|c|}{$W / L$} & \multirow{2}{*}{$\begin{array}{c}\text { AAGR } \\
\underline{X} \\
\end{array}$} & \multicolumn{4}{|c|}{$B / L$} & \multirow{2}{*}{$\begin{array}{c}\text { AAGR } \\
\underline{x} \\
\end{array}$} \\
\hline & 1968 & $\underline{1976}$ & 1981 & 1986 & & 1968 & 1976 & 1981 & 1986 & \\
\hline Food & 25.2 & 26.7 & 26.0 & 27.9 & $0.57 \%$ & 74.8 & 73.3 & 74.0 & 72.1 & $-0.20 x$ \\
\hline Tobacco & 14.0 & 22.3 & 28.6 & 38.2 & 5.73 & 86.0 & 77.7 & 71.4 & 61.8 & -1.82 \\
\hline Textiles & 13.5 & 17.7 & 16.3 & 20.9 & 2.46 & 86.5 & 82.3 & 83.7 & 79.1 & -0.50 \\
\hline Apparel & 14.4 & 17.2 & 16.4 & 15.9 & 0.55 & 85.6 & 82.8 & 83.6 & 84.1 & -0.10 \\
\hline $\begin{array}{l}\text { Lumber } \\
\& \text { Wood }\end{array}$ & 13.2 & 11.5 & 16.9 & 17.4 & 1.55 & 86.8 & 88.5 & 83.1 & 82.6 & -0.28 \\
\hline $\begin{array}{l}\text { Furniture } \\
\& \text { Fixtures }\end{array}$ & 22.4 & 19.4 & 19.5 & 21.7 & -0.18 & 77.6 & 80.6 & 80.5 & 78.3 & 0.05 \\
\hline Paper & 24.2 & 31.5 & 29.1 & 26.1 & 0.42 & 75.8 & 68.5 & 70.9 & 73.9 & -0.14 \\
\hline $\begin{array}{l}\text { Printing } \\
\& \text { Publishin }\end{array}$ & 49.8 & 56.1 & 55.3 & 56.8 & 0.73 & 50.2 & 43.9 & 44.7 & 43.2 & -0.83 \\
\hline Chemicals & 48.8 & 46.8 & 44.7 & 54.3 & 0.60 & 51.2 & 53.2 & 55.3 & 45.7 & -0.63 \\
\hline Petroleum & 58.7 & 63.4 & 45.8 & 48.4 & -1.07 & 41.3 & 36.6 & 54.2 & 51.6 & 1.24 \\
\hline Rubber & 25.4 & 20.4 & 25.4 & 22.4 & -0.70 & 74.6 & 79.6 & 74.6 & 77.6 & 0.22 \\
\hline Leather & 19.4 & 11.7 & 12.9 & 19.6 & 0.06 & 80.6 & 88.3 & 87.1 & 80.4 & -0.01 \\
\hline $\begin{array}{l}\text { Clay } \\
\text { \& Glass }\end{array}$ & 26.6 & 21.7 & 24.8 & 24.6 & -0.43 & 73.4 & 78.3 & 75.2 & 75.4 & 0.15 \\
\hline $\begin{array}{r}\text { Primary } \\
\text { Metals }\end{array}$ & 18.8 & 20.3 & 19.1 & 22.4 & 0.98 & 81.2 & 79.7 & 80.9 & 77.6 & .0 .25 \\
\hline $\begin{array}{l}\text { Fabricated } \\
\text { Metals }\end{array}$ & 28.4 & 25.5 & 27.1 & 29.0 & 0.12 & 71.6 & 74.5 & 72.9 & 71.0 & -0.05 \\
\hline Machinery & 31.3 & 34.6 & 36.0 & 43.0 & 1.78 & 68.7 & 65.4 & 64.0 & 57.0 & -1.03 \\
\hline $\begin{array}{l}\text { Electric } \\
\text { Machinery }\end{array}$ & 35.7 & 34.3 & 37.7 & 46.2 & 1.44 & 64.3 & 65.7 & 62.3 & 53.8 & -0.99 \\
\hline Instruments & 50.3 & 45.0 & 39.4 & 54.2 & 0.42 & 49.7 & 55.0 & 60.6 & 45.8 & -0.45 \\
\hline $\begin{array}{l}\text { Transporta- } \\
\text { tion Equipt }\end{array}$ & 31.1 & 29.5 & 30.6 & 35.9 & 0.80 & 68.9 & 70.5 & 69.4 & 64.1 & -0.04 \\
\hline Misc. Mfg. & 24.2 & 27.5 & 25.7 & 30.9 & 1.37 & 75.8 & 72.5 & 74.3 & 69.1 & -0.51 \\
\hline Total Mfg. & 29.4 & 28.7 & 31.2 & 35.8 & 1.10 & 70.6 & 71.3 & 68.9 & 64.2 & -0.53 \\
\hline
\end{tabular}

Note: Since $L=W+B$, the $B / L$ and $W / L$ shares sum to $100 \%$ in each year. 
Table 4

EDUCATIONAL COMPOSITION OF WHITE COLLAR LABOR HOURS, U.S. MANUFACTURING

\begin{tabular}{|c|c|c|c|c|c|c|c|c|}
\hline \multirow[b]{2}{*}{ Industry } & \multicolumn{2}{|c|}{ NHS } & \multicolumn{2}{|c|}{ HS } & \multicolumn{2}{|c|}{ sc } & \multicolumn{2}{|c|}{ c } \\
\hline & 1976 & 1986 & 1976 & 1986 & 1976 & 1986 & $\underline{1976}$ & $\underline{1986}$ \\
\hline Food & 10.2 & 8.3 & 48.6 & 44.8 & 15.4 & 20.0 & 25.8 & 26.9 \\
\hline Tobacco & 13.4 & 0.0 & 45.0 & 23.9 & 0.0 & 38.7 & 41.6 & 37.4 \\
\hline Textiles & 18.1 & 6.3 & 35.3 & 43.9 & 24.8 & 12.4 & 21.9 & 37.4 \\
\hline Apparel & 10.2 & 6.4 & 45.0 & 41.6 & 23.9 & 19.4 & 20.9 & 32.5 \\
\hline $\begin{array}{l}\text { Lumber } \\
\& \text { Wood }\end{array}$ & 6.4 & 8.6 & 58.5 & 33.4 & 8.9 & 24.3 & 26.2 & 33.7 \\
\hline $\begin{array}{l}\text { Furniture } \\
\& \text { Fixtures }\end{array}$ & 10.0 & 8.3 & 50.9 & 31.0 & 18.5 & 21.5 & 20.6 & 39.3 \\
\hline Paper & 5.1 & 2.1 & 40.7 & 39.6 & 18.4 & 16.6 & 35.8 & 41.7 \\
\hline $\begin{array}{l}\text { Printing } \\
\& \text { Publishing }\end{array}$ & 9.1 & 4.7 & 40.8 & 35.6 & 22.2 & 26.9 & 27.9 & 32.7 \\
\hline Chemicals & 4.7 & 3.8 & 28.6 & 27.5 & 21.6 & 18.5 & 45.1 & 50.1 \\
\hline Petroleum & 4.6 & 2.9 & 22.4 & 34.2 & 31.5 & 22.3 & 41.5 & 40.6 \\
\hline Rubber & 6.0 & 0.6 & 50.1 & 40.0 & 17.1 & 32.6 & 26.8 & 27.9 \\
\hline Leather & 4.9 & 6.1 & 74.8 & 50.1 & 8.8 & 8.0 & 11.5 & 35.8 \\
\hline $\begin{array}{l}\text { Clay } \\
\& \text { Glass }\end{array}$ & 11.5 & 9.2 & 48.5 & 36.1 & 17.5 & 14.2 & 22.5 & 40.5 \\
\hline $\begin{array}{l}\text { Primary } \\
\text { Metals }\end{array}$ & 6.9 & 5.0 & 31.6 & 32.9 & 23.7 & 28.8 & 37.8 & 33.3 \\
\hline $\begin{array}{l}\text { Fabricated } \\
\text { Metals }\end{array}$ & 6.1 & 4.4 & 40.9 & 34.6 & 24.4 & 25.4 & 28.7 & 35.7 \\
\hline Machinery & 4.3 & 2.3 & 40.9 & 28.6 & 22.7 & 26.5 & 32.1 & 42.7 \\
\hline $\begin{array}{l}\text { Electric } \\
\text { Machinery }\end{array}$ & 3.5 & 3.3 & 32.8 & 25.7 & 26.0 & 26.5 & 37.7 & 44.6 \\
\hline Instruments & 4.8 & 2.6 & 29.9 & 27.8 & 30.0 & 22.0 & 35.3 & 47.7 \\
\hline $\begin{array}{l}\text { Transporta- } \\
\text { tion Equipt. }\end{array}$ & 6.8 & 2.1 & 36.6 & 25.9 & 23.5 & 21.6 & 33.1 & 50.4 \\
\hline Misc. Mfg. & 4.5 & 6.0 & 51.1 & 43.7 & 28.1 & 18.7 & 16.3 & 31.7 \\
\hline Total Mfg. & 7.1 & 3.9 & 38.7 & 31.8 & 22.8 & 23.3 & 31.4 & 41.0 \\
\hline
\end{tabular}

Notes: The shares are the proportion of hours in each category relative to total white collar (non-production) labor hours. NHS is no high school, HS is high school, SC is some college, and $C$ is college degree. 
Table 5

EDUCATIONAL COMPOSITION OF BLUE COLLAR LABOR HOURS, U.S. MANUFACTURING

\begin{tabular}{|c|c|c|c|c|c|c|c|c|}
\hline \multirow[b]{2}{*}{ Industry } & \multicolumn{2}{|c|}{ NHS } & \multicolumn{2}{|c|}{ HS } & \multicolumn{2}{|c|}{ sc } & \multicolumn{2}{|c|}{ C } \\
\hline & $\underline{1976}$ & 1986 & $\underline{1976}$ & $\underline{1986}$ & 1976 & $\underline{1986}$ & $\underline{1976}$ & $\underline{1986}$ \\
\hline Food & 48.2 & 36.1 & 42.1 & 50.8 & 7.7 & 8.9 & 2.0 & 4.2 \\
\hline Tobacco & 43.3 & 14.7 & 34.5 & 51.8 & 9.9 & 19.8 & 7.3 & 13.7 \\
\hline Textiles & 62.9 & 40.1 & 33.1 & 49.0 & 4.0 & 8.7 & 0.0 & 2.2 \\
\hline Apparel & 57.9 & 49.9 & 38.5 & 44.9 & 3.1 & 4.0 & 0.5 & 1.2 \\
\hline $\begin{array}{l}\text { Lumber } \\
\& \text { Wood }\end{array}$ & 49.6 & 36.2 & 37.3 & 51.7 & 11.4 & 10.6 & 1.6 & 1.4 \\
\hline $\begin{array}{l}\text { Furniture } \\
\& \text { Fixtures }\end{array}$ & 51.3 & 43.4 & 41.3 & 46.3 & 6.4 & 7.6 & 1.0 & 2.7 \\
\hline Paper & 36.7 & 19.7 & 51.6 & 61.2 & 11.0 & 15.7 & 0.7 & 3.5 \\
\hline $\begin{array}{l}\text { Printing } \\
\& \text { Publishing }\end{array}$ & 27.4 & 15.8 & 57.7 & 58.8 & 10.6 & 17.8 & 4.3 & 7.6 \\
\hline Chemicals & 29.1 & 18.0 & 51.1 & 60.5 & 14.0 & 14.8 & 5.9 & 6.7 \\
\hline Petroleum & 24.1 & 11.9 & 57.8 & 63.6 & 11.8 & 18.7 & 6.2 & 5.9 \\
\hline Rubber & 43.1 & 35.9 & 48.8 & 49.1 & 5.2 & 13.1 & 2.9 & 1.8 \\
\hline Leather & 56.9 & 53.7 & 38.9 & 40.8 & 4.2 & 3.2 & 0.0 & 2.3 \\
\hline $\begin{array}{l}\text { Clay } \\
\& \text { Glass }\end{array}$ & 46.0 & 36.8 & 43.2 & 47.2 & 8.9 & 13.6 & 1.8 & 2.4 \\
\hline $\begin{array}{l}\text { Primary } \\
\text { Metals }\end{array}$ & 40.9 & 32.8 & 48.7 & 51.6 & 7.6 & 10.8 & 2.8 & 4.8 \\
\hline $\begin{array}{l}\text { Fabricated } \\
\text { Metals }\end{array}$ & 42.5 & 29.7 & 47.6 & 54.0 & 7.8 & 13.6 & 2.1 & 2.7 \\
\hline Machinery & 30.5 & 23.2 & 54.2 & 57.4 & 12.5 & 15.2 & 2.7 & 4.2 \\
\hline $\begin{array}{l}\text { Electric } \\
\text { Machinery }\end{array}$ & 32.8 & 23.0 & 53.9 & 55.9 & 11.9 & 14.2 & 1.5 & 6.8 \\
\hline Instruments & 40.0 & 23.2 & 42.7 & 55.0 & 14.6 & 14.6 & 2.7 & 7.1 \\
\hline $\begin{array}{l}\text { Transporta- } \\
\text { tion Equipt. }\end{array}$ & 36.1 & 25.6 & 49.5 & 52.9 & 12.7 & 17.1 & 1.6 & 4.3 \\
\hline Misc. Mfg. & 49.8 & 40.4 & 43.4 & 40.8 & 4.7 & 12.5 & 2.1 & 6.2 \\
\hline Total Mfg. & 43.0 & 30.2 & 45.8 & 52.8 & 9.1 & 12.8 & 2.1 & 4.2 \\
\hline
\end{tabular}

Notes: The shares are the proportion of hours in each category relative to total blue collar (production) labor hours. NHS is no high school, hS is high school diploma, $\mathrm{SC}$ is some college, and $\mathrm{C}$ is college degree. 
Table 6

LABOR INTENSITY REGRESSIONS WITH LNIY AS DEPENDENT VARIABLE (absolute value of $t$-statistics in parentheses)

\begin{tabular}{|c|c|c|c|c|c|c|}
\hline Industry & C & $\ln (K / Y)$ & $\ln (O F / K)$ & $\ln (E O / K)$ & $t$ & $-\mathrm{B}^{2}$ \\
\hline Food & $(0.436)$ & $(0.23)$ & $(0.56)$ & $\begin{array}{l}2.496 \\
(1.03)\end{array}$ & $(2.017)$ & .988 \\
\hline Tobacco & $(i .18)$ & $\left(i^{106} .21\right)$ & $(i .51)$ & $\left(i^{342} .72\right)$ & $=(.027 *$ & .896 \\
\hline Textiles & $\begin{array}{c}-848 \\
(0.82)\end{array}$ & $\because .067)$ & $\left(\begin{array}{c}128 \\
0.93)\end{array}\right.$ & $\begin{array}{l}-1.759 \\
(1.23)\end{array}$ & $\begin{array}{l}.040 \% \\
(4.24)\end{array}$ & .979 \\
\hline Apparel & $\begin{array}{l}1.206 \\
(i .12)\end{array}$ & $(2.39)$ & $\left(i^{281} .60\right)$ & -.106 & $=.051 *$ & .976 \\
\hline $\begin{array}{l}\text { Lumber \& } \\
\text { Wood }\end{array}$ & $\left(\begin{array}{l}160 \\
(0.44)\end{array}\right.$ & $\left(i^{204} .37\right)$ & $\left(\dot{2}^{100 *} .59\right)$ & $(i .06)$ & $=022 *$ & .906 \\
\hline $\begin{array}{l}\text { Furniture } \& \\
\text { Fixtures }\end{array}$ & $\begin{array}{l}-1.754 \\
(1.97)\end{array}$ & $\left(3^{276 *}\right)$ & $\left(\begin{array}{c}010 \\
0.18)\end{array}\right.$ & $\begin{array}{l}-1.004 * \\
(2.21)\end{array}$ & $\begin{array}{l}.029 * \\
(5.89)\end{array}$ & .966 \\
\hline Paper & $\left(\begin{array}{c}.009 \\
0.03)\end{array}\right.$ & $(0.059)$ & $\left(\begin{array}{c}010 \\
(0.14)\end{array}\right.$ & $\begin{array}{l}1.681 \\
(1.56)\end{array}$ & $(3.030 *$ & .985 \\
\hline $\begin{array}{l}\text { Printing } \alpha \\
\text { Publishing }\end{array}$ & $\begin{array}{l}-.778 \\
(0.83)\end{array}$ & $\left(\begin{array}{l}070 \\
0.86)\end{array}\right.$ & $(0.026)$ & $\begin{array}{l}-.782 \\
(0.55)\end{array}$ & $(3.30)$ & .873 \\
\hline Chemicals & $\begin{array}{l}-1.958 \star \\
(5.35)\end{array}$ & $(0.94)$ & $(2.95)$ & $\begin{array}{l}-2.994 * \\
(4.51)\end{array}$ & $\begin{array}{l}=.050 * \\
(5.94)\end{array}$ & .940 \\
\hline Petroleum & $\begin{array}{l}-1.541 \\
(1.12)\end{array}$ & $(0.478)$ & $(2.51)$ & $=(0.215)$ & $(i .16)$ & .481 \\
\hline Rubber & $\frac{1.401}{(1.67)}$ & $(0.045)$ & $\left(\dot{4}^{284 *} .27\right)$ & $\begin{array}{l}2.160 \\
(1.16)\end{array}$ & $(2.31)$ & .889 \\
\hline Leather & $\begin{array}{l}-1.718 \\
(1.54)\end{array}$ & $(0.55)$ & $\left(\begin{array}{c}128 \\
(0.59)\end{array}\right.$ & $(i .56)$ & $-(i .916)$ & .754 \\
\hline Clay \& Glass & $\begin{array}{l}-798 * \\
(5.22)\end{array}$ & $\begin{array}{l}-003 \\
(0.03)\end{array}$ & $\left(\begin{array}{c}016 \\
(0.74)\end{array}\right.$ & $\left(i^{340} .95\right)$ & $(3.015 *$ & .892 \\
\hline $\begin{array}{l}\text { Primary } \\
\text { Metals }\end{array}$ & $(0.052)$ & $\left(\dot{3}^{218 *} 46\right)$ & $\left(i^{148} .88\right)$ & $=0.081$ & $\begin{array}{l}-.030 * \\
(6.08)\end{array}$ & .895 \\
\hline $\begin{array}{l}\text { Fabricated } \\
\text { Metals }\end{array}$ & $\left(\begin{array}{c}906 \\
0.87)\end{array}\right.$ & $\begin{array}{l}-.015 \\
(0.20)\end{array}$ & $\left(i^{092}\right)$ & $\begin{array}{l}3.484 \\
(1.91)\end{array}$ & $=.028 *$ & .903 \\
\hline Machinery & $(0.06)$ & -.072 & $\left(\begin{array}{c}145 \\
(0.21)\end{array}\right.$ & $\left(\begin{array}{c}921 \\
(0.20)\end{array}\right.$ & $(1.033)$ & .964 \\
\hline $\begin{array}{l}\text { Electric } \\
\text { Machinery }\end{array}$ & $\begin{array}{l}1.692 \\
(1.82)\end{array}$ & $(2.184 *$ & $\left(2^{413 *}\right.$ & $\begin{array}{l}1.441 \\
(1.93)\end{array}$ & $\begin{array}{c}.054 * \\
(6.62)\end{array}$ & .992 \\
\hline Instruments & $\begin{array}{l}-318 \\
(0.40)\end{array}$ & $\begin{array}{l}-048 \\
(0.67)\end{array}$ & $\left(\begin{array}{l}172 * \\
(8.01)\end{array}\right.$ & $(\dot{0} 581)$ & $(i 1.20)$ & .988 \\
\hline $\begin{array}{l}\text { Transporta- } \\
\text { tion Equipt }\end{array}$ & $\begin{array}{l}2.341 * \\
(4.51)\end{array}$ & $(2.70)$ & $\left(\begin{array}{c}456 * \\
(6.01)\end{array}\right.$ & $\begin{array}{l}3.727 * \\
(3.34)\end{array}$ & $\begin{array}{l}-.058 * \\
(8.85)\end{array}$ & .929 \\
\hline Misc. Mfg. & $\begin{array}{l}1.015 \\
(0.75)\end{array}$ & $(3.30)$ & $\left(i^{164} .50\right)$ & $\left(\begin{array}{c}564 \\
0.79\end{array}\right)$ & $\overline{(2.023 *}$ & .735 \\
\hline
\end{tabular}


HIGH-TECH CAPITAL FORMATION AND LABOR COMPOSITION

- Page 35 -

Table 7

WHITE COLLAR LABOR INTENSITY REGRESSIONS WITH LNWY AS DEPENDENT VARIABLE (absolute value of $t$-statistics in parentheses)

\begin{tabular}{|c|c|c|c|c|c|c|}
\hline Industry & $\underline{\mathrm{C}}$ & $\ln (K / Y)$ & $\underline{\ln (O F / K)}$ & $\ln (E Q / K)$ & $\underline{t}$ & $\underline{\mathrm{R}}^{2}$ \\
\hline Food & $\begin{array}{l}9.907 \\
(1.03)\end{array}$ & $\left(\begin{array}{c}032 \\
(0.04)\end{array}\right.$ & $\begin{array}{l}2.274 \\
(1.49)\end{array}$ & $\begin{array}{l}22.801 \\
(1.00)\end{array}$ & $(0.036)$ & .200 \\
\hline Tobacco & $\begin{array}{l}-5.467 \\
(1.33)\end{array}$ & $\left(\begin{array}{l}492 \\
(0.79)\end{array}\right.$ & $\begin{array}{l}-.412 \\
(0.69)\end{array}$ & $\begin{array}{l}-.027 \\
(0.02)\end{array}$ & $(1.14)$ & .420 \\
\hline Textiles & $\begin{array}{l}6.440 \\
(1.74)\end{array}$ & $-9.968)$ & $\begin{array}{l}1.254 * \\
(2.61)\end{array}$ & $\begin{array}{l}9.855 \\
(1.85)\end{array}$ & $=.080 x$ & .566 \\
\hline Apparel & $\begin{array}{l}-4.734 \\
(0.56)\end{array}$ & $\begin{array}{c}-.293 \\
(0.22)\end{array}$ & $\begin{array}{l}-.407 \\
(0.29)\end{array}$ & $(0.125)$ & $\begin{array}{c}.007 \\
(0.07)\end{array}$ & .338 \\
\hline $\begin{array}{l}\text { Lumber \& } \\
\text { Wood }\end{array}$ & $\begin{array}{l}-1.927 \\
(1.04)\end{array}$ & -.234 & $(i .00)$ & $\left(\begin{array}{c}589 \\
(0.31)\end{array}\right.$ & $\begin{array}{l}-.007 \\
(0.33)\end{array}$ & .217 \\
\hline $\begin{array}{c}\text { Furniture } \& \\
\text { Fixtures }\end{array}$ & $\begin{array}{l}5.334 \\
(0.94)\end{array}$ & $\begin{array}{c}.445 \\
(0.83)\end{array}$ & $\begin{array}{l}0.584 \\
(1.76)\end{array}$ & $\begin{array}{l}2.950 \\
(1.02)\end{array}$ & $\begin{array}{l}-.075 * \\
(2.42)\end{array}$ & .420 \\
\hline Paper & -8.831 & $\begin{array}{l}-1.034 \\
(1.62)\end{array}$ & $\begin{array}{l}1.091 * \\
(2.09)\end{array}$ & $\begin{array}{l}-13.070 \\
(1.70)\end{array}$ & $-.152 *$ & 397 \\
\hline $\begin{array}{l}\text { Printing \& } \\
\text { Publishing }\end{array}$ & $\begin{array}{l}5.428 \\
(1.49)\end{array}$ & $\begin{array}{l}0.186 \\
(0.59)\end{array}$ & $\left(i^{461} .91\right)$ & $\begin{array}{l}10.096 \\
(1.82)\end{array}$ & $(\dot{007})$ & .224 \\
\hline Chemicals & $\begin{array}{l}-3.816 * \\
(3.36)\end{array}$ & $\left(\begin{array}{l}301 \\
0.67)\end{array}\right.$ & $=.604$ & $\begin{array}{l}-4.557 * \\
(2.21)\end{array}$ & $\begin{array}{l}-.043 \\
(1.67)\end{array}$ & .470 \\
\hline Petroleum & $\begin{array}{l}-1.138 \\
(0.44)\end{array}$ & $(0.121)$ & $\begin{array}{c}.680 * \\
(2.79)\end{array}$ & $=(0.319)$ & $(i .057)$ & .527 \\
\hline Rubber & $(0.143)$ & $\begin{array}{l}-159 \\
(0.24)\end{array}$ & $\left(i^{470} .32\right)$ & $(\dot{0.086})$ & $\begin{array}{l}-.020 \\
(0.70)\end{array}$ & .160 \\
\hline Leather & $\begin{array}{l}1.701 \\
(0.33)\end{array}$ & $(\dot{370})$ & $\begin{array}{l}1.965 \\
(2.00)\end{array}$ & $\begin{array}{l}-2.621 \\
(1.06)\end{array}$ & $\left(0^{0.520}\right)$ & .338 \\
\hline Clay \& Glass & $\begin{array}{r}-1.863 \\
(2.06)\end{array}$ & $\left(\begin{array}{c}023 \\
(0.03)\end{array}\right.$ & $\begin{array}{c}125 \\
(0.99)\end{array}$ & $\begin{array}{c}.950 \\
(0.92)\end{array}$ & $(1.037)$ & .185 \\
\hline $\begin{array}{l}\text { Primary } \\
\text { Metals }\end{array}$ & $\begin{array}{l}-5.342 \\
(1.83)\end{array}$ & $\left(i^{407} .31\right)$ & $\begin{array}{c}347 \\
(0.90)\end{array}$ & $\begin{array}{l}-10.085 \\
(1.28)\end{array}$ & $\begin{array}{l}-.009 \\
(0.38)\end{array}$ & .331 \\
\hline $\begin{array}{l}\text { Fabricated } \\
\text { Metals }\end{array}$ & $\begin{array}{l}-5.057 \\
(0.75)\end{array}$ & $\begin{array}{l}-.429 \\
(0.90)\end{array}$ & $\begin{array}{l}.063 \\
(0.15)\end{array}$ & $\begin{array}{l}-4.242 \\
(0.36)\end{array}$ & $\begin{array}{l}.026 \\
(0.35)\end{array}$ & .138 \\
\hline Machinery & $\begin{array}{l}-3.875 \\
(0.59)\end{array}$ & $\begin{array}{l}.066 \\
(0.26)\end{array}$ & $\begin{array}{c}-304 \\
(0.21)\end{array}$ & $\begin{array}{l}-4.647 \\
(0.47)\end{array}$ & $=(1.083)$ & .495 \\
\hline $\begin{array}{l}\text { Electric } \\
\text { Machinery }\end{array}$ & $\begin{array}{c}185 \\
(0.06)\end{array}$ & $\left(\begin{array}{c}252 \\
0.91)\end{array}\right.$ & $\left(\begin{array}{c}395 \\
0.57)\end{array}\right.$ & $\left(0^{494} 18\right)$ & $=0.050$ & .816 \\
\hline Instruments & $\begin{array}{l}2.942 \\
(0.73)\end{array}$ & $\begin{array}{l}170 \\
(0.47)\end{array}$ & $\left(\begin{array}{l}428 * \\
3.95)\end{array}\right.$ & $\begin{array}{l}2.108 \\
(0.62)\end{array}$ & $(3.081)$ & .782 \\
\hline $\begin{array}{l}\text { Transporta- } \\
\text { tion Equipt }\end{array}$ & $\begin{array}{l}1.550 \\
(1.05)\end{array}$ & $\left(i^{593} .78\right)$ & $\left(\dot{2}^{612 *} .83\right)$ & $\begin{array}{l}1.197 \\
(0.38)\end{array}$ & $(3.069 x$ & .678 \\
\hline Misc. Mfg. & $\begin{array}{l}-2.469 \\
(0.56)\end{array}$ & $\begin{array}{l}1.236 * \\
(2.17)\end{array}$ & $\begin{array}{l}-.059 \\
(0.16)\end{array}$ & $(0.718)$ & $\left(\begin{array}{c}004 \\
0.12)\end{array}\right.$ & .387 \\
\hline
\end{tabular}


Table 8

BLUE COLLAR LABOR INTENSITY REGRESSIONS WITH LNBY AS DEPENDENT VARIABLE (absolute value of $t$-statistics in parentheses)

\begin{tabular}{|c|c|c|c|c|c|c|}
\hline Industry & $\underline{C}$ & $\ln (K / Y)$ & $\ln (O F / K)$ & $\underline{\ln (E Q / K)}$ & $\underline{t}$ & $\underline{\mathrm{R}}^{2}$ \\
\hline Food & $\begin{array}{l}-2.146 \\
(0.77)\end{array}$ & $\begin{array}{l}-.035 \\
(0.16)\end{array}$ & $(0.248)$ & $\begin{array}{l}1.255 \\
(0.19)\end{array}$ & $\begin{array}{l}-005 \\
(0.24)\end{array}$ & .945 \\
\hline Tobacco & $\begin{array}{l}-.050 \\
(0.03)\end{array}$ & $\begin{array}{l}-.148 \\
(0.65)\end{array}$ & $\left(i^{278} .27\right)$ & $\left(\begin{array}{l}346 \\
0.65)\end{array}\right.$ & $-.045 *$ & .833 \\
\hline Textiles & $\begin{array}{l}-2.406 \\
(1.74)\end{array}$ & $(0.091)$ & $\begin{array}{l}-.102 \\
(0.57)\end{array}$ & $\begin{array}{l}-3.064 \\
(1.54)\end{array}$ & $(2.53)$ & .966 \\
\hline Apparel & $\begin{array}{l}1.579 \\
(1.47)\end{array}$ & $(2.95)$ & $\left(\dot{2}^{373 *}\right.$ & $(0.100)$ & $=.058 \pi$ & .977 \\
\hline $\begin{array}{l}\text { Lumber } \& \\
\text { Wood }\end{array}$ & $\left(\begin{array}{l}064 \\
0.15)\end{array}\right.$ & $\left(i^{290} .63\right)$ & $(i .086)$ & $(\dot{0.905})$ & $=0.025 *$ & .914 \\
\hline $\begin{array}{c}\text { Furniture } \& \\
\text { Fixtures }\end{array}$ & $\begin{array}{l}-3.747 \star \\
(2.23)\end{array}$ & $\left(i^{222} .39\right)$ & $\left(i^{1} .1 \frac{1}{3}\right)$ & $\begin{array}{l}-1.776 \\
(2.08)\end{array}$ & $\begin{array}{l}.018 \\
(2.00)\end{array}$ & .893 \\
\hline Paper & $=.320$ & $\left(i^{360} .93\right)$ & $\dot{2} 288$ & $\begin{array}{l}6.071 * \\
(2.70)\end{array}$ & $(0.10)$ & .955 \\
\hline $\begin{array}{l}\text { Printing } \& \\
\text { Publishing }\end{array}$ & $\begin{array}{l}-6.815 * \\
(2.29)\end{array}$ & $\begin{array}{l}=.053 \\
(0.21)\end{array}$ & $(i .62)$ & $\begin{array}{l}-9.075 \\
(2.00)\end{array}$ & $\begin{array}{l}-.038 * \\
(2.15)\end{array}$ & .769 \\
\hline Chemicals & $\begin{array}{l}-1.376 \\
(1.68)\end{array}$ & $(0.084)$ & $\left(\begin{array}{l}036 \\
(0.15)\end{array}\right.$ & $\begin{array}{l}-1.451 \\
(0.98)\end{array}$ & $\begin{array}{l}: .061 \star \\
(3.23)\end{array}$ & .846 \\
\hline Petroleum & $\begin{array}{l}-3.773 \\
(1.08)\end{array}$ & $=\left(\begin{array}{c}329 \\
(0.33)\end{array}\right.$ & $\begin{array}{c}.016 \\
(0.05)\end{array}$ & $(0.09)$ & $(0.013)$ & .025 \\
\hline Rubber & $\begin{array}{l}1.340 \\
(1.21)\end{array}$ & $(0.60)$ & $(2.75)$ & $\begin{array}{l}2.971 \\
(i .21)\end{array}$ & $(i .35)$ & .852 \\
\hline Leather & $\begin{array}{l}-2.933 \\
(2.01)\end{array}$ & $\begin{array}{l}-.017 \\
(0.14)\end{array}$ & $=(207)$ & $\left(\begin{array}{c}580 \\
(0.82)\end{array}\right.$ & $\frac{.022 *}{(2.14)}$ & .667 \\
\hline Clay \& Glass & $\begin{array}{l}-1.164 * \\
(4.12)\end{array}$ & $\begin{array}{l}.042 \\
(0.19)\end{array}$ & $(0.30)$ & $\frac{.123}{(0.38)}$ & $(i .009$ & .764 \\
\hline $\begin{array}{l}\text { Primary } \\
\text { Metals }\end{array}$ & $\left(\begin{array}{c}766 \\
0.83)\end{array}\right.$ & $\left(\begin{array}{c}170 \\
(1.72)\end{array}\right.$ & $(2.35)$ & $\begin{array}{l}2.715 \\
(1.09)\end{array}$ & $\begin{array}{l}-.037 * \\
(4.68)\end{array}$ & .835 \\
\hline $\begin{array}{l}\text { Fabricated } \\
\text { Metals }\end{array}$ & $\begin{array}{l}1.927 \\
(0.94)\end{array}$ & $(0.091)$ & $\left(\begin{array}{l}127 \\
0.97)\end{array}\right.$ & $\begin{array}{l}5.822 \\
(1.64)\end{array}$ & $=044$ & .820 \\
\hline Machinery & $(0.19)$ & $\begin{array}{l}-149 \\
(0.84)\end{array}$ & $\left(0^{294}\right)$ & $\begin{array}{l}3.317 \\
(0.48)\end{array}$ & $\begin{array}{l}.010 \\
(0.21)\end{array}$ & .959 \\
\hline $\begin{array}{l}\text { Electric } \\
\text { Machinery }\end{array}$ & $\begin{array}{l}1.888 \\
(0.86)\end{array}$ & $\left(\begin{array}{c}122 \\
(0.67)\end{array}\right.$ & $\left(i^{503} .11\right)$ & $\begin{array}{l}2.380 \\
(1.35)\end{array}$ & $=0.059 *$ & .969 \\
\hline Instruments & $\begin{array}{l}-3.367 \star \\
(1.13)\end{array}$ & $\begin{array}{l}-.074 \\
(0.28)\end{array}$ & $\begin{array}{l}-.035 \\
(0.44)\end{array}$ & $\begin{array}{l}-2.281 \\
(0.71)\end{array}$ & $(i .57)$ & .884 \\
\hline $\begin{array}{l}\text { Transporta- } \\
\text { tion Equipt }\end{array}$ & $\begin{array}{l}1.880 x \\
(2.79)\end{array}$ & $\left(i^{192} .26\right)$ & $(4.02)$ & $\begin{array}{l}5.067 \star \\
(3.49)\end{array}$ & $=\frac{.054 *}{(6.33)}$ & .917 \\
\hline Misc. Mfg. & $\begin{array}{l}1.575 \\
(1.19)\end{array}$ & $\left(i^{304} .78\right)$ & $(2.39)$ & $\begin{array}{l}1.084 \\
(1.56)\end{array}$ & $=(3.034 *$ & .798 \\
\hline
\end{tabular}




\section{REFERENCES}

Allen, Steven G. [1991], "Technology and the Wage Structure," Raleigh, NC: North Carolina State University, Department of Economics, unpublished paper, May.

Attewe11, Paul [1990], "What Is Skil1?", Work and Occupations, 17:4, November, $422-448$.

Attewe11, Paul [1987], "The De-Skilling Controversy," Work and Occupations, $14: 3$, August, $323-346$.

Attewe11, Paul and James Rule [1984], "Computing and Organizations: What We know and What We Don't Know," Communications of the ACM, 27:12, December, $1184-1192$.

Barte1, Ann P. and Frank R. Lichtenberg [1987], "The Comparative Advantage of Educated Workers in Implementing New Technology, ", Review of Economics and Statistics, $69: 1$, February, 1-11.

Be11, Daniel [1963], The Coming of Post-Industrial Society, New York: Basic Books .

Berndt, Ernst R. and Laurits R. Christensen [1974], "Testing for the Existence of a Consistent Aggregate Index of Labor Inputs," American Economic Reyiew, 64:3, June, 391-404.

Berndt, Ernst R. and Catherine J. Morrison [1992], "High-Tech Capital Formation and Aggregate Economic Performance in US Manufacturing Industries: An Exploratory Analysis," Cambridge, MA: National Bureau of Economic Research, Working Paper, forthcoming.

Binswanger, Hans P. [1974], "The Measurement of Technical Change Biases with Many Factors of Production," American Economic Review, 64:5, December, 964-976.

Boozer, Michael A., Alan B. Krueger, and Shari Wolkon [1991], "Race and School Quality Since Brown vs. Board of Education, paper presented at the Brookings Institution, December. Forthcoming, Brookings Papers on Economic Activity: Microeconomics 1992.

Braverman, Harry [1974], Labor and Monopoly Capital: The Degradation of Work in the Twentieth Century, New York: Monthly Review.

Brynjolfsson, Erik [1991], "Information Technology and the 'Productivity Paradox': Mismanagement or Mismeasurement?, Cambridge, MA: MIT Sloan School of Management, unpublished manuscript, December.

Crowston, Kevin and Thomas W. Malone [1988], "Information Technology and Work Organization," Ch. 49 in M. Helander, ed., Handbook of Human-Computer Interactions, Amsterdam: Elsevier Science Publishers - North Holland, 1051-1070.

Gorman, John A., John C. Musgrave, Gerald Silverstein and Kathy Comins [1985], "Fixed Private Capital in the United States," Survey of Current Business, $65: 7$, July, 36-55. 
Griliches, Zvi [1969], "Capital-Skill Complementarity," The Review of Economics and Statistics, $51: 4$, November, $465-468$.

Hamermesh, Daniel S. [1986], "The Demand for Labor in the Long Run," ch. 8 In Orley M. Ashenfelter and Richard D. Layard, editors, Handbook of Labor Economics, Amsterdam: Elsevier Science Publishers BV, Vol. 1, 429-471.

Harper, Michael J., Ernst R. Berndt and David O. Wood [1989], "Rates of Return and Capital Aggregation Using Alternative Rental Prices," chapter 8 in Dale W. Jorgenson and Ralph Landau, eds., Technology and Capital Formation, Cambridge, MA: MIT Press, 331-372.

Howe11, David R. and Edward N. Wolff [1991], "Trends in the Growth and Distribution of Skills in the U.S. Workplace, 1960-85," Industrial and Labor Relations Review, 44:3, April, 486-502.

Howe11, David R, and Edward N. Wolff [1990], "Technical Change and the Demand for Skills by U.S. Industries, "New York University, C.V. Starr Center for Applied Economics, Research Report \#90-41, September.

Hunt, H. Allan and Timothy L. Hunt [1986], Clerical Employment and Technological Change, Kalamazoo, MI: W. E. Upjohn Institute.

Kesselman, Jonathan R., Samuel H. Williamson and Ernst R. Berndt [1977], "Tax Credits for Employment Rather than Investment," American Economic Review, 67:3, June, 339-349.

Krueger, Alan B. [1991], "How Computers Have Changed the Wage Structure: Evidence from Microdata, 1984-89," Cambridge, MA: National Bureau of Economic Research, Working Paper 3858, October.

Mincer, Jacob [1989], "Labor Market Effects of Human Capital and of its Adjustment to Technological Change, Working Paper, New York: Institute on Education and the Economy, Columbia University, February.

Morrison, Catherine J. and Ernst R. Berndt [1981], "Short-Run Labor Productivity in a Dynamic Model, "Journal of Econometrics, $16: 3$, December, 339-365.

Morrison, Catherine J. and Ernst R. Berndt [1991], "Assessing the Productivity of Information Technology Equipment in U.S. Manufacturing Industries,", Cambridge, MA: National Bureau of Economic Research, Working Paper No.' 3582, January.

Murphy, Kevin and Finis R. Welch [1988], "Wage Differences in the 1980s: The Role of International Trade," unpublished manuscript, University of California-Los Angeles, Department of Economics.

Mumford, Enid and Olive Banks [1967]. The Computer and the Clerk, London: Routledge, Kegan Paul.

Musgrave, John C. [1986], "Fixed Reproducible Tangible Wealth in the United States: Revised Estimates," Survey of Current Business, $66: 1$, January, $51-75$.

Osterman, Paul [1986], "The Impact of Computers on the Employment of Clerks and Managers," Industrial and Labor Relations Review, 39:1, January, $175-186$. 
Spenner, Kenneth I. [1985], "The Upgrading and Downgrading of Occupations: Issues, Evidence and Implications for Education," Review of Educational Research, 55:2, Summer, 125-154.

Welsh, Finis R. [1970], "Education in Production," Journal of Political Economy, 78:1, January/February, 35-59. 